\title{
Dioxin impacts on lipid metabolism of soil microbes: towards effective detection and bioassessment strategies
}

\author{
Sabrin Mahfouz ${ }^{1}$, Ghaytha Mansour', Denis J. Murphy ${ }^{2}$ and Abdulsamie Hanano ${ }^{3^{*}}$ (1)
}

\begin{abstract}
Dioxins are the most toxic known environmental pollutants and are mainly formed by human activities. Due to their structural stability, dioxins persist for extended periods and can be transported over long distances from their emission sources. Thus, dioxins can be accumulated to considerable levels in both human and animal food chains. Along with sediments, soils are considered the most important reservoirs of dioxins. Soil microorganisms are therefore highly exposed to dioxins, leading to a range of biological responses that can impact the diversity, genetics and functional of such microbial communities. Dioxins are very hydrophobic with a high affinity to lipidic macromolecules in exposed organisms, including microbes. This review summarizes the genetic, molecular and biochemical impacts of dioxins on the lipid metabolism of soil microbial communities and especially examines modifications in the composition and architecture of cell membranes. This will provide a useful scientific benchmark for future attempts at soil ecological risk assessment, as well as in identifying potential dioxin-specific-responsive lipid biomarkers. Finally, potential uses of lipid-sequestering microorganisms as a part of biotechnological approaches to the bio-management of environmental contamination with dioxins are discussed.
\end{abstract}

Keywords: Dioxins, Soil microbes, Lipid metabolism, Biodetection, Bioremediation

\section{Introduction}

Dioxins, polychlorinated dibenzodioxins (PCDDs) and polychlorinated dibenzofurans (PCDFs), are the most toxic group of persistent organic pollutants (POPs) that have been described to date (WHO 2016). Chemically, dioxins consist of two aromatic rings linked via either one or two atoms of oxygen, and give rise, respectively, to PCDFs or PCDDs. This extremely stable structure contains one to eight positions that can be chlorinated, which confers both high structural stability and extreme hydrophobicity. Depending on the number and position of chlorination $(P=1-8)$, the dioxin group includes 75 PCDD and 135 PCDF congeners that vary significantly in

\footnotetext{
*Correspondence: ashanano@aec.org.sy

${ }^{3}$ Department of Molecular Biology and Biotechnology, Atomic Energy

Commission of Syria (AECS), P.O. Box 6091, Damascus, Syria

Full list of author information is available at the end of the article
}

terms of their overall toxicity (Pollitt 1999; Caruso et al. 2003). Congeners with chlorine atoms substituted in the lateral 2, 3, 7 and 8 positions of the aromatic rings are considered as the most toxic. Of these, 2,3,7,8-tetrachlorodibenzo- $p$-dioxin (TCDD), with a toxic equivalency factor (TEF) of 1.0, is the most toxic congener of all the dioxins (WHO 2002; Van den Berg et al. 2006).

In modern settings, dioxins are mainly produced by industrial, municipal and domestic incineration (Tuppurainen et al. 2003; Tue et al. 2016; Chen et al. 2005) as well as during industrial processes involving chlorinated aromatic and aliphatic compounds, such as pesticides and herbicides synthesis (Lee et al. 1984). Also, the accidental or deliberate incineration of forest-derived and other solid materials releases considerable amounts of dioxins into the environment (Nzihou et al. 2012; Coutinho et al. 1998; Travis and Hattemer-Frey 1989). 
Due to their high structural stability and their extreme hydrophobicity, dioxins tend to persist in the environment and bioaccumulate in both human and animal food chains (Stockholm 2001). This means that humans can be exposed to dioxins through the consumption of contaminated food, which constitutes a potential health risk (WHO 2002; IPCS 2003). According to the US National Institute of Environmental Health Sciences (NIEHS), more that $90 \%$ of human exposure to dioxins occurs via ingested food rather than alternative routes such as via skin contact or inhalation (NIEHS 2017). Overall, dioxins are known to cause irreversible biological damage in human, animals, plant and microorganisms, leading to wider ecological, environmental and economic impacts (Hanano et al. 2014b, c, 2015b, 2016b, 2018b, d, 2019a, b; Latchoumycandane et al. 2003; Angrish et al. 2013; Woeller et al. 2019; Ssebugere et al. 2019; Prokopec et al. 2020).

At the beginning of many food chains, PCDD/Fs have a strong tendency to associate with soil organic materials due to their high organic carbon-water partition (KOC) coefficient. This low mobility together with low water solubility results in a high accumulation of PCDD/Fs in several types of soil (Xu et al. 2020; Meijer et al. 2001). Along with sediments, soil contains the largest reservoirs of these contaminants (Krauss and Wilcke 2003; Yao et al. 2018; Mertes et al. 2018). As a consequence, soil microorganisms are liable to be exposed to dioxins, leading to a range of biological responses that impacts the diversity, genetics and functional of affected microbial communities (Hanano et al. 2014c; Kimura and Kamagata 2009).

The cytotoxicity of dioxins in biological systems, including microorganisms, occurs mainly via their high affinity for biological macromolecules containing lipid moieties, including unbound lipids, lipoproteins and liposaccharides, thereby affecting their biological functions in living cells (Lawrence and Kerkvliet 1998; Hanano et al. 2015c, 2019b; Cranmer-Byng et al. 2015). In terms of their high octanol/water partition coefficients $\left(K_{\mathrm{ow}}\right)$, estimated at about 7.0 for TCDD, dioxins are the most lipophilic contaminants described to date (Hanson et al. 2019; Sarna et al. 1984; Marple et al. 1986; Shlu et al. 1988). This extremely high $K_{\text {ow }}$ value acts as a driving force enabling dioxins to rapidly attack lipidic macromolecules in exposed organisms, including microbes. In this context, it is important to learn more about the impacts of PCDD/Fs on the lipid metabolism of soil microbial communities. This will help in identifying potential dioxin-specific-responsive lipid biomarkers as new parameters for the soil ecological risk assessment.

This review surveys the alterations in lipid metabolism of soil microbial communities in response to dioxin exposure. It begins with a brief background on the nature of dioxins as lipophilic environmental contaminants and examines their impacts on microbial lipid metabolism with respect to the composition of cellular fatty acids (FAs). It then looks at the modifications of cell membrane architecture, especially the increased levels of unsaturated FAs that occur in response to dioxin exposure. Finally, the possible uses of lipid-sequestering microorganisms for biotechnological approaches to bio-management of dioxin in contaminated environments are outlined.

\section{Sources of dioxins in the environment}

Dioxins are released into the environment through natural sources such as volcanic activities or forest fires (Hay 1981). Such episodes are becoming more common with particular increases in the incidence of large-scale forest fires over the last decade (Salamanca et al. 2016; Zhang et al. 2016; Oliveira et al. 2020). Dioxins are also discharged into the environment by various manufacturing processes involving synthesis of chlorinated aromatic and aliphatic compounds, such as pesticide and herbicides (Chen et al. 2005) as well as paper production (Haq and Raj 2020). Other unintentional sources of dioxins include wastes containing chlorinated aromatic compounds from chemical facilities, sewage sludge, incineration of municipal and medical wastes, incineration of fossil fuels and fly ash storage (Hippelein et al. 1996). Moreover, the destruction of electronic waste (e-waste) is a considerable source of PCDD/Fs for surrounding environments, and the amount of e-waste is expected to grow to 52.2 million tons by 2021 (Jin et al. 2020). Plastic materials, such as PVC, account for about $26 \%$ of the volume of e-waste (Zheng et al. 2008; Tsydenova and Bengtsson 2011), while brominated flame retardants are used for the package of e-wastes (Kiddee et al. 2013). The methods for the processing of e-waste, such as manual disassembly, roasting, acid leaching and open burning (Nishimura et al. 2017; Ma et al. 2009; Zheng et al. 2008), lead to the formation of PCDD/Fs. Automobile emissions are another important source of PCDD/Fs. Even though leaded fuel has been banned across most of the world, diesel fuel contains $\mathrm{Cl}$ in minor amounts (Dyke et al. 2007; Zhao et al. 2014) as do the dispersants, added to retain dirt in suspension in diesel fuel mixtures (Dyke et al. 2007). This suggests that PCDD/ Fs can be formed together with other POPs in diesel engines. Finally, road transport emissions have also been identified as an important source of several halogenated POPs, such as PCDD/Fs, PCBs and polybrominated diphenyl ethers (PBDEs) (Chen et al. 2017a; Kim et al. 2003; Fuster et al. 2001; Laroo et al. 2011). 


\section{Fate and transport of dioxins in the environment}

Research conducted on the processes through which dioxins move into the environment shows that, although their formation occurs at local levels, their environmental distribution is much wider, from regional to global in reach. Once released into the environment, dioxins are distributed between specific environmental compartments. This section outlines the fate and transport processes for dioxins in the atmospheric, terrestrial and aquatic environments although, clearly, these systems are not mutually exclusive and so interact with each other. After their release, dioxins are transported through the atmosphere and deposited to terrestrial and/or aquatic surfaces. The travel distance before deposition depends upon several factors including the height of release, temperature, prevailing meteorological conditions and particle size.

Dioxins are relatively volatility and can exist in both the gaseous phase and/or bound to particles in the atmosphere, depending upon the prevailing environmental conditions, most notably temperature (Hippelein et al. 1996). Dioxins can continuously exchange between particle and vapor phases. In summer, when temperatures are high, the less chlorinated dioxin congeners tend to be found predominantly in the vapor phase, but are more likely to be bound to particles when temperatures are lower in winter (Wu et al. 2009; Shih et al. 2006; Hermanson et al. 2020; Fang et al. 2017; Birgul and Tasdemir 2011; Cindoruk and Tasdemir 2010). This is important because dioxins in the vapor phase can more readily undergo photochemical transformation to less toxic derivatives than those bound to solid substrates (Birla and Kamens 1994).

Atmospheric dioxins can move into and between terrestrial environments by direct deposition onto soil, vegetation and water surfaces via either wet or dry processes. Aquatic surfaces can be contaminated with dioxins via a direct wet or dry deposition, although direct inputs from industrial effluents and run-off from soil may also be important (Kjeller and Rappe 1995). In water, dioxins partition rapidly to solid organic matter and therefore accumulate in sediments (Beurskens et al. 1993). Interestingly, dioxins can readily partition into sedimentary clays, such as ball clays, which are fine grained and highly plastic materials with a large surface area-to-volume ratio that readily bind to such hydrophobic molecules. Subsequently, dioxins can accumulate in aquatic fauna as a direct consequence of the ingestion of contaminated organic matter, for example by filter feeding animals. As a result, the concentration of dioxins in marine animal tissues is found to increase as one moves up the food chain, a phenomenon known as biomagnification (Ahn et al. 2008; Tratnyek et al. 2020).
Due to their poor solubility in water, dioxins accumulate in most soil types, making soils the most important reservoirs of such contaminants. Above-ground terrestrial vegetation can also be exposed to dioxins by a direct deposition of atmospheric dioxins on leaves or via absorption from soil via root systems and transport via the vascular system to aerial tissues such as leaves and flowers (Reischl et al. 1988; Chrostowski and Foster 1996; Engwall and Hjelm 2000; Hanano et al. 2015b, 2018b, d). Here, it is important to note that leafy crops, such as salads, are less affected by direct deposition of dioxins because of their relatively brief lifetime in the field, which is often limited to a few weeks. However, even leafy crops can be exposed to dioxins indirectly from contaminated soil due to their active root systems (Hanano et al. 2014b, $2018 b)$. Longer lived perennial and woody plants can accumulate considerable amount of dioxins from the surrounding atmosphere as well as via their well-developed root systems (Hanano et al. 2016b, 2018d). More research is needed to define and evaluate the modalities by which plants can be exposed to dioxins, compared to animals that are directly exposed via contaminated feed (Torres et al. 2013; Diletti et al. 2007).

\section{Bioavailability of dioxins}

The bioavailability of a soil contaminant is routinely defined by the degree to which it may be absorbed and metabolized by biological systems (ISO/FDIS 2008). Some of limitations of this definition, notably in terms of the temporal and species dependence are discussed in detail by Harmsen et al. (2005). Semple et al. (2003) addressed these limitations by proposing two different components of bioavailability: (i) the bioavailability component where a compound is freely available to cross an organism's cellular membrane at a given time. After transfer has occurred, storage, transformation, assimilation or degradation within the organism can occur. These processes are distinct from the original transfer from the medium. (ii) The bioaccessibility component, where a compound can cross an organism's cellular membrane from the environment only if the organism has a direct access to the chemical. Although the details of these definitions have been debated, it is obvious that organic compound bioavailability is intimately related to three factors: (i) the physicochemical properties of the compound; (ii) the physicochemical properties of the soil type, and finally; (iii) the current environmental conditions at the time of potential exposure (Meric et al. 2014; Smidova et al. 2017).

The bioavailability of dioxins is conditioned by their extremely low water solubility and strong affinity to organic particles in soils, which in turn, are also continuously targeted by soil microorganisms. This can 
facilitate the initial interactions between dioxins and soil microorganisms. The uptake mechanism of hydrophobic compounds in general, and dioxins in particular, is a key aspect of their biodegradation process within cells, because they need to cross the cell membrane in order to be accessible to the relevant membrane-bound enzymes. Some soil microorganisms are able to increase the bioavailability of dioxins by quantitative and qualitative modification of cell membrane lipids, hence modulating the fluidity and permeability of the cell membrane and facilitating the uptake of the dioxins (Aguilar-Uscanga and Francois 2003; Hanano et al. 2019b). It was also reported that the most active microorganisms in term of dioxin uptake from the aquatic environment are those that produce biosurfactants as secreted substances that tend to reduce liquid surface tensions, thereby acting as emulsifying agent for the dioxins (Hanano et al. 2014a, 2015c).

Several microbiological methods have been developed to measure the bioavailability of dioxins. They include measurement of dioxin biodegradability because the biodegradable fraction is also considered to be the bioavailable fraction (Richterich et al. 1998). Mineralization assays are also used where the conversion of ${ }^{14} \mathrm{C}$-labeled dioxins into ${ }^{14} \mathrm{CO}_{2}$ gives a measure of the microbially available fraction of the contaminant (Hatzinger and Alexander 1995; Semple et al. 2003). Microbial toxicity tests have also been applied, but these do not necessarily measure the bioavailable compound faction (Jacobs et al. 1993). Another technique in microbial measurement is the use of microbial biosensors, which has widespread applications in environmental monitoring and toxicity assessment and considerable advantages in terms of sensitivity, cost and time compared to using higher organisms (Steinberg et al. 1995).

In this context, genetic manipulation can enhance the sensitivity of biosensor towards a target compound and reporter genes for bacterial bioluminescence (lux) have been used (Palmer et al. 1998). In this strategy, which has been used for a range of hydrophobic organic pollutants including dioxins, a given metabolic stress induced by an environmental toxicant results in a decline in luminescence that is directly proportional to the toxicant concentration (Boyd et al. 1997; Sousa et al. 2009).

\section{Lipophilicity of dioxins}

The lipophilicity of dioxins, i.e., their extreme affinity for cellular lipids, is a major determinant factor of their toxicity (Geyer et al. 1993). The lipophilicity of an organic compound is experimentally described by a partition coefficient, LogP, defined as the ratio of the concentration for an unionized compound at equilibrium between organic and aqueous phases (Marple et al. 1986). Different dioxin congeners (there are 210 in total) possess a range of physicochemical properties. Seventeen of them are of interest for their potential toxicity to humans and other organisms. Therefore, knowledge of properties of individual dioxins is necessary in order to determine the behavior of dioxins pool, which are typically found as mixtures in the environment, and this is important for predicting and possibly mitigating the fate, transport and the toxicological effects of dioxins in humans.

In environmental modeling, $n$-octanol partitioning is routinely used as a more convenient alternative to biological systems. Hence, the ability of dioxins to partition between air or water and $n$-octanol is used as a proxy measure of their ability to bio-concentrate in plants, animals and fish. Here, two main parameters are described, namely the $n$-octanol:water or $n$-octanol:air partition coefficients, $K_{\text {ow }}$ and $K_{\text {oa }}$, respectively, although for many of dioxin congeners there is substantial uncertainty about their value (Mackay et al. 1982; Marple et al. 1986). Table 1 summarizes the octanol:water partition coefficient $\left(K_{\text {ow }}\right)$ values of the most potent congeners of dioxins. This table shows that values of $K_{\text {ow }}$ are positively correlated with the chlorination degree of dioxins. Thus, a high value $K_{\mathrm{ow}}$ value reflects a high affinity to cellular fats and possibly a high subsequent toxicity in an organism. However, the tetrachlorinated dibenzo- $p$-dioxin congeners, known for their extreme toxicity in biological systems, do not have the highest $K_{\text {ow }}$ values. Obviously,

\begin{tabular}{lll}
$\begin{array}{l}\text { Table 1 Octanol-water } \\
\text { of some PCDDs }\end{array}$ & partition & coefficient (log Kow) \\
\hline Dioxin substituent & Log Kow & References \\
\hline $\begin{array}{l}\text { Dibenzo-p-dioxin } \\
\text { l-Chloro- }\end{array}$ & 4.30 & Shlu et al. (1988) \\
2-Chloro- & 4.75 & Sarna et al. (1984) \\
2,3-Dichloro- & 5.00 & Hanson et al. (2019) \\
2,7-Dichloro- & 5.60 & Sarna et al. (1984) \\
2,8-Dichloro- & 5.75 & Hanson et al. (2019) \\
1,2,4-Trichloro- & 5.60 & Shlu et al. (1988) \\
& 6.35 & Hanson et al. (2019), Shlu et al. \\
1,2,3,4-Tetrachloro- & 6.60 & Sarna et al. (1984) \\
1,2,3,7-Tetrachloro- & 6.90 & Burkhard et al. (1994), Shlu et al. \\
& & (1988) \\
1,3,6,8-Tetrachloro- & 7.10 & Sarna et al. (1984) \\
1,3,7,9-Tetrachloro- & 7.10 & Marple et al. (1986) \\
2,3,7,8-Tetrachloro- & 7.20 & Marple et al. (1986) \\
1,2,3,4,7-Pentachloro- & 7.40 & Shlu et al. (1988), Sarna et al. \\
& & (1984) \\
1,2,3,4,7,8-Hexachloro- & 7.80 & Marple et al. (1986) \\
1,2,3,4,6,7,8-Heptachloro- & 8.00 & Sarna et al. (1984), Shlu et al. \\
& & (1988) \\
1,2,3,4,6,7,8,9-Octachloro- & 8.20 & Marple et al. (1986), Shlu et al. \\
& & (1988) \\
\hline
\end{tabular}


the high toxicity of such substituents of dioxins is conditioned by their efficiency in penetrating biological systems and their subsequent interactions with cellular components. For this reason, the 'Toxic Equivalent' (TEQ) concept is used to assess the potential toxicity of a mixture of dioxins in exposed organisms (Safe 1990). This factor indicates the degree of toxicity compared to 2,3,7,8-TCDD, the most toxic congener of dioxins which has been universally assigned a TEF value of 1 .

Lipids are promising cellular components to be targeted for bio-environmental studies. This is because lipids are highly abundant and ubiquitous across all organisms, and their profiles can often be substantially modified in response to a wide range of environmental stimuli (Depatie et al. 2020; Tang et al. 2018). Such lipidic alterations can allow organisms to maintain essential biological functions while adapting to environmental changes including toxic contaminants. Much research has been conducted to determine the major metabolic responses in lipid metabolism of microorganisms exposed to environmental stressors, including persistent toxicants (Tartu et al. 2017). The overall lipidic profile of an organism, or part thereof, at a given time is referred to as the lipidome. The relatively new discipline of lipidomics helps us to understand the biofeedback processes affecting lipid metabolism in responding to historical environmental changes, and can help predict similar responses in the future (Depatie et al. 2020). Lipid metabolism can be affected at anabolic and catabolic levels due to the regulation of enzymes controlling lipid metabolism at transcriptional and biochemical levels (Pakiet et al. 2019; Russo et al. 2020; Sollai et al. 2019). Cell membrane lipids, which are the first lipidic barrier enabling the cell to manage communication with the surrounding milieu, are typically subjected to considerable qualitative and quantitative alterations according to the nature and level of exposure to environmental contaminants (Albergamo et al. 2016). These interactive responses in lipid metabolism of microorganisms exposed to dioxins are reviewed in detail as follows.

\section{Effects of dioxins on lipid metabolism in soil microorganisms}

There are multiple lines of genetic, molecular and biochemical evidence demonstrating that dioxins, notably TCDD, alter lipid metabolism by affecting the activity of certain key enzymes in fatty acids (FAs) biosynthesis, levels of triacylglycerols, cholesterols and free FAs in plasma of animals, plants and humans exposed to dioxins. In contrast, relatively little is known about similar exposure patterns involving soil microorganisms (Hanano et al. 2014b, 2015b, 2016b, 2018c, 2019a, b).
Soil microorganisms are readily subjected to dioxin exposure and respond by a range of biological alterations that can influence microbial diversity and functionality (Cerniglia 1984; Hanano et al. 2014c). Enzymatic activity is now considered as one of the most useful indicators for assessing exposure levels of microbial communities to stressors (Yao et al. 2018; Field and Sierra-Alvarez 2008; Anasonye et al. 2014; Le et al. 2017). Consequently, many bacterial and somewhat fewer fungal species have been identified and characterized as potential bioindicators and/or biodegraders of dioxins (Hiraishi et al. 2001, 2003b; Hanano et al. 2019a; Stella et al. 2017; Magan et al. 2010; Rubilar et al. 2011). Omics-based studies, including genomics, transcriptomics, proteomics, and metabolomics have given much useful information about microbial responses to environmental challenges. This has enabled the extrapolation of results from a relatively small-scale omics studies to a wide diversity of organisms, and the compilation of risk assessments and remediation strategies applicable to entire ecosystems (Brinke and Buchinger 2017).

Lipidomics is an emerging field where hundreds to thousands of lipid molecular species are simultaneously measured qualitatively and quantitatively (Koelmel et al. 2020). Lipids participate in metabolic reactions controlling cellular energy balance and also serve as major structural components in membranes, as well as acting as substrates for the generation of signaling compounds and other cellular mediators (Konings et al. 2002). Therefore, lipidomics can be used to determine lipid biomarkers against a specific contaminant exposure that affects certain biochemical pathways, including FA biosynthesis, lipid peroxidation and oxidative stress (Albergamo et al. 2016). Several biological systems have been evaluated for biodegradation of dioxins, such as bacterial angular dioxygenases (Sato et al. 1997; Armengaud et al. 1998; Habe et al. 2001), peroxidases of white-rot fungi and anaerobic dehalogenases from microbial consortia (Bumpus et al. 1985; Bunge et al. 2003). The effects of dioxins on lipid metabolism of soil microorganisms have been studied in vitro using a selected microorganism isolated from dioxin-exposed environment and this approach has been used with a large variety of soil microorganisms, including bacteria, yeast and fungi (Hanano et al. 2014c, 2019a, b).

In the 1970s, Fulco et al. were the first to shed light on the biological connection between exposure to dioxins and cytochrome P450 in Bacillus megaterium ATCC 14581, which was initially characterized as an oxygenase of monounsaturated FAs (Matson et al. 1977). In the 1980 s, the same group reported a detailed characterization of three different isoforms of cytochrome P450 in B. megaterium, referred as to $\mathrm{P} 450_{\mathrm{BM}-1}, \mathrm{P} 450_{\mathrm{BM}-2}$ and 
P450 ${ }_{\mathrm{BM}-3}$ (Kim and Fulco 1983; Narhi et al. 1983; Schwalb et al. 1985). Of these, $\mathrm{P} 450_{\mathrm{BM}-3}$, the best characterized isoform, is a catalytically self-sufficient monooxygenase that requires $\mathrm{NADPH}$ and $\mathrm{O}_{2}$ to catalyze the hydroxylation and epoxidation of monounsaturated FAs (Matson et al. 1977; Ruettinger and Fulco 1981; Narhi and Fulco 1987). Interestingly, orthologs of these bacterial P450s were identified in hepatic microsomal fractions of rat and human that can metabolize dioxins via multiple catalytic mechanisms (Inouye et al. 2002; Sakaki et al. 2002; Shinkyo et al. 2003a, b; Sulistyaningdyah et al. 2004). More recently, a homolog of $\mathrm{P} 450_{\mathrm{BM}-1}$ has been identified and characterized in strain BmA14K of B. megaterium, isolated from soil contaminated with dioxins which showed a remarkable ability to grow in the presence of TCDD as the sole carbon source (Hanano et al. 2019b). As a direct consequence of its exposure to TCDD, BmA14K exhibited a morphological and biophysical profile typified by high levels of biosurfactant production, surface hydrophobicity and cell membrane permeability. This is consistent with earlier reports demonstrating such behavior in B. megaterium (Thavasi et al. 2008, 2011) and other microorganisms (Bouassida et al. 2018; Paraszkiewicz et al. 2018; Plaza et al. 2016; Hanano et al. 2015d).

At the cellular level, it was shown that TCDD-grown BmA14K cells have a specific FA profile typified by low ratios of branched-chain/straight chain FAs (BCFAs/
SCFAs) and saturated/unsaturated FAs (SFAs/USFAs), plus an unusual "signature" due to the presence of branched-chain unsaturated FAs (BCUFAs), which are absent in non-exposed bacteria (Hanano et al. 2019b). In addition to their use as biomarkers in bacterial taxonomy (Guinebretiere et al. 2013), bacterial FAs compositions are considerably modulated by various environmental factors. This is known as a part of bacterial responses to environmental changes including temperature, nutrients, salts, irradiation, pressure and hydrophobic pollutants (Braganza and Worcester 1986; Diomande et al. 2015; Sikkema et al. 1995; Ayari et al. 2009; Hanano et al. 2019b). The various functions of different types of FAs in terms of environmental responses are due to their diverse structures as summarized in Table 2. FAs compositions in the genus Bacillus in general and in B. megaterium species in particular are characterized by numerous branched-chain FAs (BCFAs), with a predominance of iso and anteiso BCFAs composed of 14-17 carbons, and smaller amounts of straight chain FAs (Kaneda 1966, 1977; Choi et al. 2000; Nickels et al. 2017a, b). However, an opposite scenario, with low ratios of BCFAs/SCFAs and SFAs/USFAs, was found in TCDD-exposed bacteria (Hanano et al. 2019b). This observation is consistent with earlier reports suggesting that adaptation of certain Bacilli to environmental changes, such as decreasing temperature and $\mathrm{pH}$, involves a reduced level of BCFAs

Table 2 Environmental implications of different types of microbial membrane FAs

\begin{tabular}{|c|c|c|c|}
\hline Type of fatty acids & Structure of fatty acids ${ }^{a}$ & $\begin{array}{l}\text { Response to environment } \\
\text { factors }\end{array}$ & References \\
\hline Saturated fatty acids (SFAs) & & Decrease, low SFAs/USFAs & $\begin{array}{l}\text { Nichols et al. (1997), Hanano et al. } \\
\text { (2019b) }\end{array}$ \\
\hline $\begin{array}{l}\text { Mono-unsaturated fatty acids } \\
\text { (MUFAs) }\end{array}$ & & Decrease, low SFAs/USFAs & Hanano et al. (2019b) \\
\hline Di-unsaturated fatty acids (DUFAs) & & Increase & Kim et al. (2011), Fulco (1970) \\
\hline Poly-unsaturated fatty acids (PUFAs) & & Increase & $\begin{array}{l}\text { Silbert et al. (1973), Chen et al. } \\
\text { (2017b), Nichols et al. (1997) }\end{array}$ \\
\hline $\begin{array}{l}\text { cis-Straight chain fatty acids (cis- } \\
\text { SCFAs) }\end{array}$ & & Increase & $\begin{array}{l}\text { Pedrotta and Witholt (1999), Hanano } \\
\text { et al. (2019b) }\end{array}$ \\
\hline $\begin{array}{l}\text { trans-Straight chain fatty acids } \\
\quad \text { (trans-SCFAs) }\end{array}$ & & Increase & $\begin{array}{l}\text { Keweloh and Heipieper (1996), } \\
\text { Hanano et al. (2019b) }\end{array}$ \\
\hline $\begin{array}{l}\text { iso-Branched chain fatty acids (iso- } \\
\text { BCFAs) }\end{array}$ & & Decrease, low BCFAs/SCFAs & $\begin{array}{l}\text { Kaneda (1966), Nickels et al. (2017a), } \\
\text { Chen et al. (2017b) }\end{array}$ \\
\hline $\begin{array}{l}\text { anteiso-Branched-chain fatty acids } \\
\text { (anteiso-BCFAs) }\end{array}$ & & Decrease, low BCFAs/SCFAs & $\begin{array}{l}\text { Choi et al. (2000), Nickels et al. (2017a, } \\
\text { b), Chen et al. (2017b) }\end{array}$ \\
\hline
\end{tabular}

a Source: https://pubchem.ncbi.nlm.nih.gov/ 
and an increased level of USFAs (Silbert et al. 1973; Kaneda 1977; Chen et al. 2017b; Hong et al. 2017). In other words, TCDD-exposed bacteria exhibit a specific lipidic "signature" due to the presence of BCUFAs. The creation of such signatures can be explained by the activation of membrane-bound desaturases that act on existing branched-chain saturated FAs (BCSFAs) to produce their corresponding BCUFAs. Importantly, this lipidic "signature" was absent in bacteria grown in catechol, an intermediate of the TCDD-biodegradation pathway, suggesting that the BCUFA "signature" is specific to dioxins. In line with this, molecular and biochemical evidence have demonstrated that B. subtilis can respond rapidly to thermal changes by desaturation of existing FAs leading to a rapid modulation of membrane fluidity (Aguilar et al. 2001).

The accumulation of certain types of FAs in B. megaterium $\mathrm{A} 14 \mathrm{~K}$ as a function of dioxin exposure raises the question of their subsequent metabolizing systems and particularly about the roles of cytochrome P450 monooxygenases. In this regard, TCDD-grown $B$. megaterium A14K showed enhanced levels of $\mathrm{P} 450_{\mathrm{BM}-1}$, the smallest but the most abundant FA monooxygenase in B. megaterium (Schwalb et al. 1985). This highlights the roles of such monooxygenases in bacterial responses to TCDD and also their possible TCDD-induced subcellular targeting because these supposedly soluble enzymes also contain a putative transmembrane domain (Williams et al. 2000; Xiao et al. 2018). Interestingly, a similar scenario is found in plants and animals where the involvement of FA-metabolizing enzymes and their targeting into cytosolic lipid droplets as dioxin-responsive elements have been demonstrated (Lakshman et al. 1988, 1989; Al-Bayati and Stohs 1987, 1991; al-Bayati et al. 1988; Hanano et al. 2015b, 2016a). Together, these studies indicate that TCDD-exposed bacteria exhibit a specific profile of oxygenated FAs typified by high levels of hydroxylated and epoxidized FAs synthesized via TCDD-induced $\mathrm{P} 450_{\mathrm{BM}-1}$, and possibly other monooxygenases (Harmsen et al. 2005; Narhi and Fulco 1987; Ruettinger and Fulco 1981; Schwalb et al. 1985).

Oxygenated FAs, also termed oxylipins, are well known as essential molecules enabling animals, plants and microorganisms to respond to various forms of biotic and abiotic stress (Mohammadpour et al. 1988; Bestervelt et al. 1994; Hanano et al. 2018d). In microorganisms, oxylipins play crucial roles in regulating the biosynthesis of secondary metabolite (Hanano et al. 2018a, 2019a), as well as the production of biosurfactants and their emulsifying activity towards hydrophobic compounds (Hanano et al. 2014a, 2015c, 2017, 2019b). Oxylipins have also roles in altering bacterial membrane fluidity as a function of environmental stress (Denich et al. 2003). For these reasons, the signatures of the various FAs and their metabolites have been proposed to be used as biomarkers for biomonitoring the exposure of animals, plants and soil microorganisms to dioxins (Hiraishi et al. 2003a; Bassompierre et al. 2007; Hanano et al. 2018d, 2019b).

Soil fungi can also be exposed to soil contaminants, such as dioxins, and hence could be used to assess their toxicity and possibly their biodegradation (Miao et al. 2020; Bilal et al. 2019). The in vitro exposure of a soil-dwelling strain of the fungus Aspergillus flavus to dioxin results in a phenotype typified by a reduction in vegetative growth and a tendency to conidiation, which has similarities with the 'wasting syndrome' in observed in animals experimentally exposed to TCDD (Tuomisto et al. 1995; Tsujimoto et al. 2013; Hutin et al. 2018; Hanano et al. 2019a). Furthermore, dioxin-exposed fungi exhibit an unusual cellular FA profile (Hanano et al. 2019a). This dioxin-specific FA pattern in fungal cells is related to an enhanced level of a lipid-binding caleosin/ peroxygenase, called AfPXG, which catalyzes the reduction of FA hydroperoxides (FA-OOH) to their corresponding alcohols (AF-OH), similarly to the action of orthologous caleosin/peroxygenases in plants (Hanano et al. 2006, 2018c). The biological impacts of such peroxygenase activity in oxylipin biosynthesis pathway have been well characterized in plants (Blee et al. 2014; Charuchinda et al. 2015), but much less in fungi (Fan et al. 2015). However, an AfPXG gene knockout in A. flavus resulted in a considerable accumulation of FA-OOH in fungal tissues combined with developmental anomalies and a reduced level of aflatoxin production (Hanano et al. 2015a).

Beside of its enzymatic activity, AfPXG has a structural role in cellular lipid droplet (LD) assembly. Caleosinencoding genes are present in many, but not all, publicly available fungal genomic sequences including all Aspergillus sp. The encoded caleosin protein sequences harbor at least one copy of a highly conserved lipidbinding domain enabling the proteins to be integrated into the monolayer membrane of LDs as well as into conventional bilayer membranes (Murphy 2012; Rahman et al. 2018; Hanano et al. 2015a). The structural role of fungal caleosins in impacting the assembly and the stability of LDs is well demonstrated (Froissard et al. 2009; Jamme et al. 2013; Ortiz-Urquiza et al. 2016; Zhu et al. 2015; Zeng et al. 2017). In connection with exposure to dioxin, TCDD-exposed fungi expressed more AfPXG and accumulated more LDs than controls, which probably aids the fungal cells to sequester dioxin into LDs. Similar induction of caleosin isoforms was also reported in plants experimentally exposed to TCDD (Hanano et al. 2016b, 2018d). These data highlight the possible effects of dioxins on aflatoxicogenicity of A. flavus. The presence 
of fungal-derived toxins could be a major problem in certain foods, with implications for human health and also for wider food security. In conclusion, soil microbes directly exposed to dioxins experience significant but predictable changes to their cellular lipid metabolism and their subsequent lipid profiles. Such alterations can assist in the identification of dioxin-specific lipid biomarkers in soil microorganisms as a part of strategies to monitor, control and remediate such contaminants.

\section{Effects of dioxins on cell membrane lipids}

Bacterial cell membranes have important homeostatic functions in maintaining optimal intercellular conditions for metabolism and energy transduction. To achieve this, bacteria can dynamically modify the structure of their cell membrane as a function of environmental changes. The modulation of membrane lipid composition is the most common adaptive strategy used by soil microorganisms for responding to environment changes such as temperature and $\mathrm{pH}$, a phenomenon known as homeoviscous adaptation (Di Pasqua et al. 2006; Heipieper et al. 2003; Holtwick et al. 1999; Russell and Fukanaga 1990). Unlike eukaryotes, bacteria can modulate membrane fluidity by changing the proportion of iso- and anteisobranched FAs, by isomerization of cis unsaturated FAs (UFAs) to corresponding trans isomers, and also by altering the average FAs chain length, protein binding, and overall FA composition (Fujita et al. 2007; Fulco 1983).

Lipids have many important functions in microbial cells, both as membrane components and more broadly as metabolic intermediates (Cronan and Gelmann 1975; Fulco 1983; Russell and Fukanaga 1990). In particular, lipids are involved in environmental sensing and adaptation; hence variations in temperature, $\mathrm{pH}$, ethanol concentration, salts, irradiation, antibiotics and toxic compounds, that affect microbial growth and transition to the stationary phase, can also lead to alteration in FAs content and membrane viscosity (Russell 1984). For example, there is a universally conserved microbial adaptive response in modulating FAs unsaturation to adjust membrane fluidity (Suutari et al. 1990; Suutari and Laakso 1994; Hanano et al. 2015d, 2019b; Loffeld and Keweloh 1996; Keweloh and Heipieper 1996). The lipophilic character of dioxins enables them to partition into the lipid bilayer of bacterial cell membranes, disturbing the overall lipid and protein packing, hence rendering the membrane more permeable (Evans et al. 1998; Bayer et al. 2000; Mrozik et al. 2004). It was found that the total FA content and the percentage of membrane PUFAs, notably C16:2 and C18:2, were significantly increased in a stain of baker's yeast, Saccharomyces cerevisiae, grown on aromatic hydrocarbons (Hanano et al. 2015d). This adaptive modification proceeded at two levels. Quantitatively, the increase of total FAs is explained by activation of FA biosynthesis from corresponding terminally hydroxylated alkanes that are accumulated proximately to the endoplasmic reticulum via adjacent peroxisomal fatty alcohol oxidases and fatty aldehyde dehydrogenases (Fukui and Tanaka 1981). On the other hand, increases in PUFAs can be explained by their architectural necessity in the cell membrane to enhance its fluidity. Several reports have suggested that $S$. cerevisiae increases unsaturated FAs in the membrane and this increases membrane fluidity in the presence of alcohols (Kim et al. 2011). As S. cerevisiae does not naturally produce polyunsaturated FAs (Ratledge and Wynn 2002), the appearance of PUFAs, notably $\mathrm{C} 16: 2$ and $\mathrm{C} 18: 2$, in aromatic hydrocarbongrown yeast is surprising. Although $S$. cerevisiae produces monounsaturated FAs of 16- and 18-carbons via a $\Delta 9$-desaturase, which is capable of producing C16:1 and C18:1 (Stukey et al. 1989), other species of Saccharomyces such as $S$. kluyveri can produce di-unsaturated FAs C16:2 and C18:2 via a $\Delta 12$-desaturase (Kainou et al. 2006). However, the presence of new isoforms of desaturase in yeast grown with aromatic hydrocarbons remains to be demonstrated. A similar adaptive scenario was recently reported for TCDD-exposed $B$. megaterium A14K that exhibited a specific lipidic "signature" due to the presence of branched-chain unsaturated fatty acids (BCUFAs) (Hanano et al. 2019b). This suggests a possible activation of membrane-bound desaturases that act on existing branched-chain saturated FAs (BCSFAs) in cell membrane to produce the corresponding BCUFAs, which are tentatively considered as lipid biomarkers to dioxin exposure (Hanano et al. 2019b).

As reported by Russell (1984), the mechanisms by which bacterial cells can alter the unsaturation ratio of membrane FAs depend on the mechanism of FA biosynthesis. The author described two distinct and mutually exclusive UFAs biosynthetic pathways in bacteria, an anaerobic and an aerobic pathway. The former is used by anaerobes and some facultative aerobes and produces UFAs by de novo synthesis through the action of a FA synthase (de Mendoza et al. 1983; Russell 1984). The latter produces only saturated FAs, via multisubunit membrane desaturase enzymes (Russell 1997). Figure 1 summarizes the possible cellular and molecular pathways by which dioxins can impact the synthesis of FAs, and subsequently, the composition of cell membrane, modifying its fluidity and permeability. On the other hand, adaptation to $\mathrm{pH}$ in Escherichia coli and Salmonella enterica resulted in a decrease of UFA content, suggesting that the mechanism depends on the type of stressor (Yuk and Marshall 2004; Chiou et al. 2004). Increased FA length is another important membrane alteration to increase survival in acidic environments and a similar mechanism 
Fig. 1 Schematic model of molecular and biochemical impacts of dioxins on lipid biosynthesis and cell membrane composition in soil microorganisms. Due to their extreme lipophilicity, dioxins show a high affinity towards cellular lipids. After their uptake, dioxins can affect the metabolism of microbial FAs by two distinct and mutually exclusive UFA biosynthetic pathways in bacteria, an anaerobic and an aerobic pathway. (1) The first is used by anaerobes and some facultative aerobic microorganisms leading to produce UFAs by de novo synthesis under the action of an FA synthase. (2) The other produces only saturated FAs, via multisubunit associated-membrane desaturases. This generally modifies the composition of cellular FAs leading to decreasing ratios of saturated FAs/unsaturated FAs (SFAs/ USFAs), branched-chain FAs/straight chain FAs (BCFAs/SCFAs). It also leads to the generation of an unusual FAs such as branched-chain unsaturated FAs (BCUSFAs), which enhances the fluidity and permeability of the cell membrane. The spectrum of unusual FAs produced as part of dioxin responses in these bacteria gives rise to specific "lipidic signatures" that can be used as part of diagnostic and remediation strategies to address such environmental pollutants

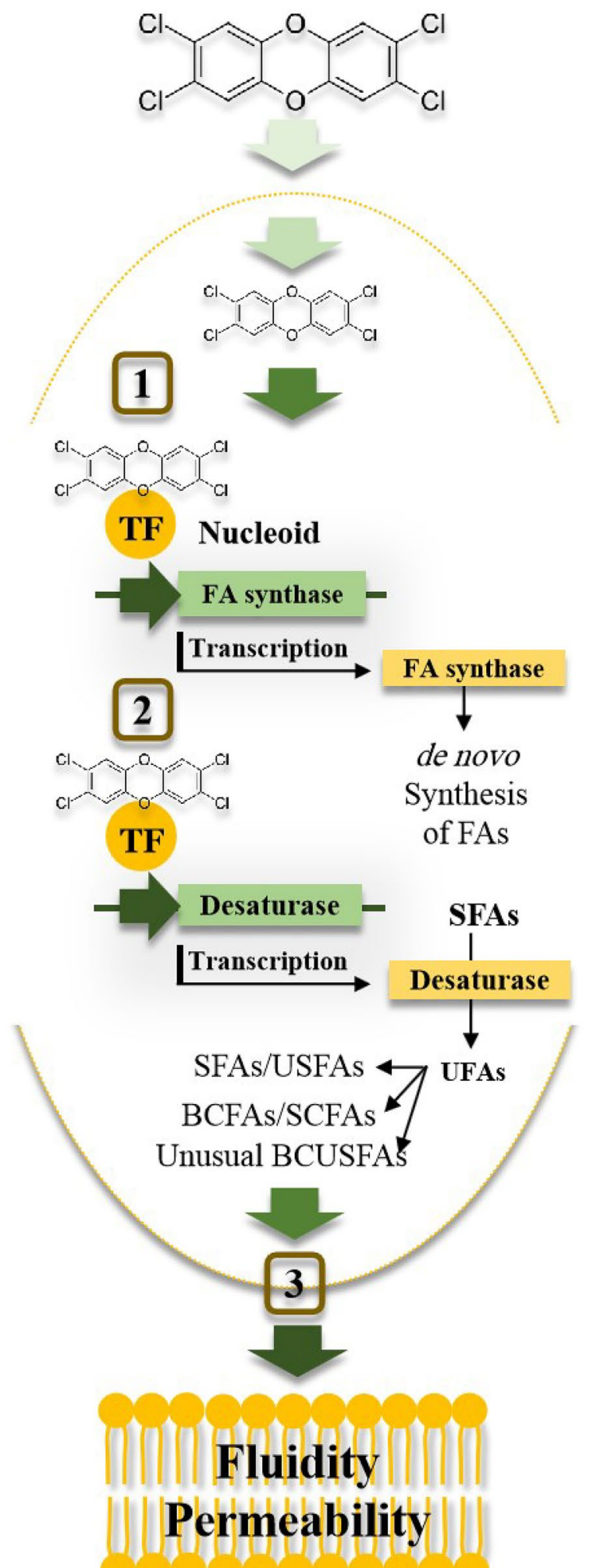


probably occurs when the cells grow in the presence of antimicrobial compounds. In E. coli O157:H7, shortmedium chain FAs (C4-C14) and long chain FAs (C20C22) were either absent or present in low concentrations under control conditions (Fozo and Quivey 2004a, b).

\section{Biotechnological strategies and future prospects}

The ultimate goal of research into microbe-contaminant interactions is to identify microbes that can effectively take up, metabolize, and thus minimize the environmental concentration of contaminant, a process known as biodegradation (Gavrilescu and Chisti 2005; Wagner et al. 2002). Most research into biodegradation involves a "single-microorganism" strategy. However, selection of the "best" microorganism that removes a given contaminant from the environment in a "perfect" manner remains a big challenge. Indeed, identifying the "best" microorganism is often frustrating because of the traditional culturing methods of microorganisms that did not guarantee a full success. This process is applied particularly to culturable microorganisms, although it is estimated that only $0.1-10 \%$ of soil microorganisms can be cultured in vitro. Therefore, traditional laboratory-based approaches provide very limited information on the true diversity of soil microbial community and hence the potential utility of hitherto uncultivated species (Kalivas et al. 2017; Kakirde et al. 2010; Shen et al. 2007).

It is therefore necessary to 'think outside the box', for example where modern environmental metagenomics is revealing a huge diversity of hitherto undiscovered and uncultivated soil-dwelling species that might have interesting biotechnological properties for removing of contaminants. In this regard, it was interestingly shown that archaea have novel ether-based FAs, rather than the ester-based FAs found in bacteria and eukaryotes. Archaeal membranes containing such ether-based lipids are known to have uniquely resilient properties allowing their adaptation to many forms of environmental stresses, including highly extreme stresses (Gurr et al. 2016).

Another challenge is selecting a microbe in a natural environment, where it is quite hard to predict its biologi$\mathrm{cal} /$ functional behavior in different habitats and as part of a wider microbial community at a given environmental site (Koelmel et al. 2020). In this respect, it is worth noting that dioxin biodegradation is a complex biochemical process. This is due to the diversity of dioxin-metabolizing microbial systems, to the biochemical diversity of the enzymes initiating the first step in dioxin biodegradation, and finally to the diversity of environmental factors required by a given microbial species. To minimize this complexity, alternative approaches basing on the cultureindependent genomic analysis of microbial communities, i.e., metagenomics, have been developed (Schloss and Handelsman 2003; Rondon et al. 2000; Shen et al. 2007).

Metagenomics approaches are derived from the statistical concept of meta-analysis (the process of statistically combining separate analyses) and genomics (the comprehensive analysis of an organism's genetic material) (Rondon et al. 2000). In metagenomics, two complementary approaches, function-driven analysis and sequencedriven analysis, are combined to extract biological information from metagenomics datasets. The former is initiated by identification of clones expressing desired traits, followed by their characterization via sequence and biochemical analysis. This allows a rapid identification of functional clones that have potential involvement in dioxin biodegradation pathways. The sequence-driven analysis approach uses highly conserved DNA sequences to design hybridization probes or PCR primers to screen metagenomics libraries for clones that contain sequences of interest.

Significant discoveries have also emerged from random sequencing of metagenomic clones carrying phylogenetic anchors, such as the $16 S$ rRNA gene and the archaeal DNA repair gene (radA) (Beja et al. 2000a, b, 2001; Quaiser et al. 2002; Schleper et al. 1998; Suzuki et al. 2001), and have provided functional information about the organisms from which these clones were derived. Without doubt, the use of metagenomics for studying interactions between soil microbes and contaminants in general, and dioxins in particular, will considerably assist the screening of soil microbes including bacteria, archaea, viruses and fungi, irrespective of their culturability and taxonomic identities. As a result, it is possible that such approaches could lead to modification of the current conventional microbiological strategy for dioxin degradation based on single microbe-based analysis to a more sophisticated and biologically relevant communitybased analysis, thus leading to new strategies for dioxin bio-management.

With respect to dioxin specificity, the use of lipidomics, in combination with metagenomics, can help to better characterize lipidic signatures symptomatic of soil microorganisms subjected to dioxins exposure. To date, the limited number of environmental lipidomics studies does not reflect the potential applicability of this approach in environmental science, rather, it may reflect: (i) an unawareness of lipidomics as a tool for environmental scientists; (ii) the cost of sample analysis using highresolution mass spectrometers, and (iii) the high-level of bioinformatics expertise needed for data processing and interpretation. Somewhat more controversially, genetically engineered microorganisms have attracted some attention and might be a complementary biotechnological strategy for remediation of dioxin-contaminated 
environments. For example, it might be possible to engineer microorganisms with combinations of enzyme systems, such as angular dioxygenase, cytochrome P450, lignin peroxidase, and dehalogenase that could act as efficient dioxin-metabolizing biosystems (Sakaki and Munetsuna 2010).

\section{Conclusions}

Soils, and therefore soil microbial communities, can be highly exposed to dioxin contamination. Due to their extreme lipophilicity, dioxins tend to mostly affect lipid metabolism in exposed microbes, leading to the production of dioxin-specific "signatures" of specific cellular FAs, and the modulation of the FA composition of cell membranes. This review emphasizes the importance of lipidic signatures in term of their specificity and consequent ability for use as tools to assess and monitor the exposure of soil microbes to dioxins. It also underlines the use of metagenomics coupled with lipidomics as potentially powerful approaches to providing an overall image of the lipidic responses of soil microbial communities after exposure to dioxins. It finally suggests that effective remediation strategies for dioxins in contaminated soil require approaches based on community dynamics rather than targeting single microbes. Future biotechnological approaches for biosensing and bioremediation of dioxin-contaminated environments will be greatly facilitated by use of data provided by such metagenomic/lipidomic approaches.

\begin{abstract}
Abbreviations
PCDDs: Polychlorinated dibenzodioxins; PCDFs: Polychlorinated dibenzofurans; POPs: Persistent organic pollutants; TCDD: Tetrachlorodibenzo-p-dioxin; PCDD/Fs: Polychlorinated dibenzo- $p$-dioxin/furans; TEF: Toxic equivalency factor; KOC: Organic carbon-water partition; Kow: Octanol/water partition coefficients; Koa: Octanol:air partition coefficients; FAs: Fatty acids; TEQ: Toxic equivalent; PCBs: Polychlorinated biphenyls; LogP: Partition coefficient; BCFAs/ SCFAs: Branched-chain/straight chain Fas; SFAs/USFAs: Saturated/unsaturated Fas; BCUFAS: Branched-chain unsaturated Fas; AfPXG: Caleosin/peroxygenase; LDs: Lipid droplets; radA: Archaeal DNA repair gene.
\end{abstract}

\section{Acknowledgements}

We would like to address a special thanks to the International Network on Microbial Ecotoxicology (EcotoxicoMic) (https://ecotoxicomic.org/) for its crucial support throughout our research activities and more particularly during the preparation of this review.

\section{Authors' contributions}

SM and GM collected related materials and drafted the manuscript. $\mathrm{AH}$ conceptualized and wrote the manuscript. DM revised and edited the manuscript. All authors read and approved the final manuscript.

\section{Funding}

The authors declare that this work did not receive any funding.

\section{Availability of data and materials}

All datasets on which the conclusions of the manuscript rely are presented in the main paper.
Ethics approval and consent to participate Not applicable.

\section{Consent for publication}

Not applicable.

\section{Competing interests}

The authors declare that they have no financial and non-financial competing interests.

\author{
Author details \\ 1 Department of Plant Biology, Faculty of Sciences, University of Damascus, \\ Damascus, Syria. ${ }^{2}$ Genomics and Computational Biology Group, Univer- \\ sity of South Wales, Pontypridd, UK. ${ }^{3}$ Department of Molecular Biology \\ and Biotechnology, Atomic Energy Commission of Syria (AECS), P.O. Box 6091, \\ Damascus, Syria.
}

Received: 29 June 2020 Accepted: 30 October 2020

Published online: 07 November 2020

\section{References}

Aguilar PS, Hernandez-Arriaga AM, Cybulski LE, Erazo AC, de Mendoza D (2001) Molecular basis of thermosensing: a two-component signal transduction thermometer in Bacillus subtilis. EMBO J 20(7):1681-1691. https:// doi.org/10.1093/emboj/20.7.1681

Aguilar-Uscanga B, François JM (2003) A study of the yeast cell wall composition and structure in response to growth conditions and mode of cultivation. Lett Appl Microbiolo 37:268-274. https://doi.org/10.1046/ j.1472-765X.2003.01394.x

Ahn YB, Liu F, Fennell DE, Haggblom MM (2008) Biostimulation and bioaugmentation to enhance dechlorination of polychlorinated dibenzo-pdioxins in contaminated sediments. FEMS Microbiol Ecol 66(2):271-281. https://doi.org/10.1111/j.1574-6941.2008.00557.x

Al-Bayati ZA, Stohs SJ (1987) The role of iron in 2,3,7,8-tetrachlorodibenzop-dioxin-induced lipid peroxidation by rat liver microsomes. Toxicol Lett 38(1-2):115-121

Al-Bayati ZA, Stohs SJ (1991) The possible role of phospholipase A2 in hepatic microsomal lipid peroxidation induced by 2,3,7,8-tetrachlorodibenzop-dioxin in rats. Arch Environ Contam Toxicol 20(3):361-365

Al-Bayati ZA, Wahba ZZ, Stohs SJ (1988) 2,3,7,8-Tetrachlorodibenzo-p-dioxin (TCDD)-induced alterations in lipid peroxidation, enzymes, and divalent cations in rat testis. Xenobiotica 18(11):1281-1289. https://doi. org/10.3109/00498258809042251

Albergamo A, Rigano F, Purcaro G, Mauceri A, Fasulo S, Mondello L (2016) Free fatty acid profiling of marine sentinels by nanoLC-EI-MS for the assessment of environmental pollution effects. Sci Total Environ 571:955-962. https://doi.org/10.1016/j.scitotenv.2016.07.082

Anasonye F, Winquist E, Kluczek-Turpeinen B, Räsänen M, Salonen K, Steffen KT, Tuomela M (2014) Fungal enzyme production and biodegradation of polychlorinated dibenzo-p-dioxins and dibenzofurans in contaminated sawmill soil. Chemosphere 110:85-90

Angrish MM, Dominici CY, Zacharewski TR (2013) TCDD-elicited effects on liver, serum, and adipose lipid composition in C57BL/6 mice. Toxicol Sci 13:108-115

Armengaud J, Happe B, Timmis KN (1998) Genetic analysis of dioxin dioxygenase of Sphingomonas sp. Strain RW1: catabolic genes dispersed on the genome. J Bacteriol. 180(15):3954-3966

Ayari S, Dussault D, Millette M, Hamdi M, Lacroix M (2009) Changes in membrane fatty acids and murein composition of Bacillus cereus and Salmonella Typhi induced by gamma irradiation treatment. Int J Food Microbiol 135(1):1-6. https://doi.org/10.1016/j.ijfoodmicro.2009.07.012

Bassompierre M, Tomasi G, Munck L, Bro R, Engelsen SB (2007) Dioxin screening in fish product by pattern recognition of biomarkers. Chemosphere 67(9):S28-35. https://doi.org/10.1016/j.chemosphere.2006.05.087

Bayer AS, Prasad R, Chandra J, Koul A, Smriti M, Varma A, Skurray RA, Firth N, Brown MH, Koo SP, Yeaman MR (2000) In vitro resistance of Staphylococcus aureus to thrombin-induced platelet microbicidal protein is associated with alterations in cytoplasmic membrane fluidity. Infect Immun 68(6):3548-3553. https://doi.org/10.1128/iai.68.6.3548-3553.2000 
Beja O, Aravind L, Koonin EV, Suzuki MT, Hadd A, Nguyen LP, Jovanovich SB, Gates CM, Feldman RA, Spudich JL, Spudich EN, DeLong EF (2000a) Bacterial rhodopsin: evidence for a new type of phototrophy in the sea. Science 289(5486):1902-1906. https://doi.org/10.1126/scien ce.289.5486.1902

Beja O, Suzuki MT, Koonin EV, Aravind L, Hadd A, Nguyen LP, Villacorta R, Amjadi M, Garrigues C, Jovanovich SB, Feldman RA, DeLong EF (2000b) Construction and analysis of bacterial artificial chromosome libraries from a marine microbial assemblage. Environ Microbiol 2(5):516-529. https://doi.org/10.1046/j.1462-2920.2000.00133.x

Beja O, Spudich EN, Spudich JL, Leclerc M, DeLong EF (2001) Proteorhodopsin phototrophy in the ocean. Nature 411(6839):786-789. https://doi. org/10.1038/35081051

Bestervelt LL, Piper DW, Pitt JA, Piper WN (1994) Lipid peroxidation in the adrenal glands of male rats exposed to 2,3,7,8-tetrachlorodibenzo-p-dioxin (TCDD). Toxicol Lett 70(2):139-145

Beurskens JEM, Mol GAJ, Barreveld HL, Vv M, Winkels HJ (1993) Geochronology of priority pollutants in a sedimentation area of the Rhine River. Environ Toxicol Chem 12:9. https://doi.org/10.1002/etc.5620120905

Bilal M, Adeel M, Rasheed T, Zhao Y, labal HMN (2019) Emerging contaminants of high concern and their enzyme-assisted biodegradation - a review. Environ Int 124:336-353. https://doi.org/10.1016/j.envint.2019.01.011

Birgul A, Tasdemir Y (2011) Seasonal atmospheric deposition variations of polychlorinated biphenyls (PCBs) and comparison of some deposition sampling techniques. Environ Sci Pollut Res Int 18(3):396-406. https:// doi.org/10.1007/s11356-010-0383-2

Birla P, Kamens RM (1994) Effect of combustion temperature on the atmospheric stability of polybrominated Dibenzo-p-dioxins and Dibenzofurans. Environ Sci Technol 28(8):1437-1443. https://doi.org/10.1021/ es00057a010

Blee E, Boachon B, Burcklen M, Le Guedard M, Hanano A, Heintz D, Ehlting J, Herrfurth C, Feussner I, Bessoule JJ (2014) The reductase activity of the Arabidopsis caleosin RESPONSIVE TO DESSICATION20 mediates gibberellin-dependent flowering time, abscisic acid sensitivity, and tolerance to oxidative stress. Plant Physiol 166(1):109-124. https://doi. org/10.1104/pp.114.245316

Bouassida M, Ghazala I, Ellouze-Chaabouni S, Ghribi D (2018) Improved biosurfactant production by Bacillus subtilis SPB1 mutant obtained by random mutagenesis and its application in enhanced oil recovery in a sand system. J Microbiol Biotechnol 28(1):95-104. https://doi.org/10.4014/ jmb.1701.01033

Boyd EM, Killham K, Wright J, Rumford S, Hetheridge M, Cumming R, Meharg AA (1997) Toxicity assessment of xenobiotic contaminated groundwater using lux modified Pseudomonas fluorescens. Chemosphere 35(9):1967-1985. https://doi.org/10.1016/s0045-6535(97)00271-3

Braganza LF, Worcester DL (1986) Hydrostatic pressure induces hydrocarbon chain interdigitation in single-component phospholipid bilayers. Biochemistry 25(9):2591-2596

Brinke A, Buchinger S (2017) Toxicogenomics in environmental science. Adv Biochem Eng Biotechnol 157:159-186. https://doi. org/10.1007/10_2016_15

Bumpus JA, Tien M, Wright D, Aust SD (1985) Oxidation of persistent environmental pollutants by a white rot fungus. Science 228(4706):1434-1436

Bunge M, Adrian L, Kraus A, Opel M, Lorenz WG, Andreesen JR, Gorisch H, Lechner U (2003) Reductive dehalogenation of chlorinated dioxins by an anaerobic bacterium. Nature 421:357-360

Burkhard LP, Sheedy BR, McCauley DJ (1994) Prediction of chemical residues in aquatic organisms for a field discharge situation. Chemosphere 29(1):141-153. https://doi.org/10.1016/0045-6535(94)90096-5

Caruso JA, Klaue B, Michalke B, Rocke DM (2003) Group assessment: elemental speciation. Ecotoxicol Environ Saf 56(1):32-44. https://doi.org/10.1016/ s0147-6513(03)00048-4

Cerniglia CE (1984) Microbial metabolism of polycyclic aromatic hydrocarbons. Adv Appl Microbiol 30:31-71

Charuchinda P, Waditee-Sirisattha R, Kageyama H, Yamada D, Sirisattha S, Tanaka Y, Mahakhant A, Takabe T (2015) Caleosin from Chlorella vulgaris TISTR 8580 is salt-induced and heme-containing protein. Biosci Biotechnol Biochem 79:1119-1124

Chen L, Ran Y, Xing B, Mai B, He J, Wei X, Fu J, Sheng G (2005) Contents and sources of polycyclic aromatic hydrocarbons and organochlorine pesticides in vegetable soils of Guangzhou, China. Chemosphere 60(7):879-890. https://doi.org/10.1016/j.chemosphere.2005.01.011 Chen SJ, Tsai JH, Chang-Chien GP, Huang KL, Wang LC, Lin WY, Lin CC, Yeh CK (2017) Emission factors and congener-specific characterization of $\mathrm{PCDD} / \mathrm{Fs}, \mathrm{PCBs}, \mathrm{PBDD} / \mathrm{Fs}$ and PBDEs from an off-road diesel engine using waste cooking oil-based biodiesel blends. J Hazard Mater 339:274-280. https://doi.org/10.1016/j.jhazmat.2017.06.045

Chen Y, Liu M, Chen S, Wei X (2017) Decreased formation of branched-chain short fatty acids in Bacillus amyloliquefaciens by metabolic engineering. Biotechnol Lett 39(4):529-533. https://doi.org/10.1007/s1052 9-016-2270-5

Chiou RY, Phillips RD, Zhao P, Doyle MP, Beuchat LR (2004) Ethanol-mediated variations in cellular fatty acid composition and protein profiles of two genotypically different strains of Escherichia coli O157:H7. Appl Environ Microbiol 70(4):2204-2210. https://doi.org/10.1128/ aem.70.4.2204-2210.2004

Choi KH, Heath RJ, Rock CO (2000) beta-ketoacyl-acyl carrier protein synthase III (FabH) is a determining factor in branched-chain fatty acid biosynthesis. J Bacteriol 182(2):365-370

Chrostowski CP, Foster AS (1996) A methodology for assessing congenerspecific partitioning and plant uptake of dioxins and dioxin-like compounds. Chemosphere 32:2285-2304

Cindoruk SS, Tasdemir Y (2010) Dynamics of atmospheric polychlorinated biphenyls (PCBs): concentrations, patterns, partitioning, and dry deposition level estimations in a residential site of Turkey. Environ Monit Assess 162(1-4):67-80. https://doi.org/10.1007/s10661-009-0776-1

Coutinho M, Conceicao M, Borrego C, Nunes M (1998) Atmospheric impact assessment and monitoring of dioxin emissions of municipal solid waste incinerators in Portugal. Chemosphere 37(9-12):2119-2126. https://doi.org/10.1016/s0045-6535(98)00274-4

Cranmer-Byng MM, Liddle DM, De Boer AA, Monk JM, Robinson LE (2015) Proinflammatory effects of arachidonic acid in a lipopolysaccharideinduced inflammatory microenvironment in 3T3-L1 adipocytes in vitro. Appl Physiol Nat Metab 40:142-154

Cronan JE Jr, Gelmann EP (1975) Physical properties of membrane lipids: biological relevance and regulation. Bacteriol Rev 39(3):232-256

de Mendoza D, Klages Ulrich A, Cronan JE Jr (1983) Thermal regulation of membrane fluidity in Escherichiacoli. Effects of overproduction of betaketoacyl-acyl carrier protein synthase I. J Biol Chem 258(4):2098-2101

Denich TJ, Beaudette LA, Lee H, Trevors JT (2003) Effect of selected environmental and physico-chemical factors on bacterial cytoplasmic membranes.J Microbiol Methods 52(2):149-182

Depatie C, Houde M, Verreault J (2020) Environmental exposure of northern pike to a primary wastewater effluent: impact on the lipidomic profile and lipid metabolism. Aquat Toxicol 221:105421. https://doi. org/10.1016/j.aquatox.2020.105421

Di Pasqua R, Hoskins N, Betts G, Mauriello G (2006) Changes in membrane fatty acids composition of microbial cells induced by addiction of thymol, carvacrol, limonene, cinnamaldehyde, and eugenol in the growing media. J Agric Food Chem 54(7):2745-2749. https://doi.org/10.1021/ jf0527221

Diletti G, Ceci R, De Benedictis A, Migliorati G, Scortichini G (2007) Determination of dioxin-like polychlorinated biphenyls in feed and foods of animal origin by gas chromatography and high resolution mass spectrometry. Veterinaria Italiana 43(1):129-140

Diomande SE, Nguyen-The C, Guinebretiere MH, Broussolle V, Brillard J (2015) Role of fatty acids in Bacillus environmental adaptation. Front Microbiol 6:813. https://doi.org/10.3389/fmicb.2015.00813

Dyke PH, Sutton M, Wood D, Marshall J (2007) Investigations on the effect of chlorine in lubricating oil and the presence of a diesel oxidation catalyst on PCDD/F releases from an internal combustion engine. Chemosphere 67(7):1275-1286. https://doi.org/10.1016/j.chemospher e.2006.12.010

Engwall M, Hjelm K (2000) Uptake of dioxin-like compounds from sewage sludge into various plant species-assessment of levels using a sensitive bioassay. Chemosphere 40(9-11):1189-1195. https://doi. org/10.1016/s0045-6535(99)00368-9

Evans Rl, McClure PJ, Gould GW, Russell NJ (1998) The effect of growth temperature on the phospholipid and fatty acyl compositions of nonproteolytic Clostridium botulinum. Int J Food Microbiol 40(3):159-167. https://doi.org/10.1016/s0168-1605(98)00029-4 
Fan Y, Ortiz-Urquiza A, Garrett T, Pei Y, Keyhani NO (2015) Involvement of a caleosin in lipid storage, spore dispersal, and virulence in the entomopathogenic filamentous fungus, Beauveria bassiana. Environ Microbiol 17(11):4600-4614. https://doi.org/10.1111/1462-2920.12990

Fang S, Cui Q, Matherne B, Hou A (2017) Polychlorinated biphenyl concentrations, accumulation rates in soil from atmospheric deposition and analysis of their affecting landscape variables along an urban-rural gradient in Shanghai, China. Chemosphere 186:884-892. https://doi. org/10.1016/j.chemosphere.2017.08.059

Field JA, Sierra-Alvarez R (2008) Microbial degradation of chlorinated dioxins. Chemosphere 71:1005-1018

Fozo EM, Quivey RG Jr (2004a) The fabM gene product of Streptococcus mutans is responsible for the synthesis of monounsaturated fatty acids and is necessary for survival at low pH. J Bacteriol 186(13):4152-4158. https://doi.org/10.1128/JB.186.13.4152-4158.2004

Fozo EM, Quivey RG Jr (2004b) Shifts in the membrane fatty acid profile of Streptococcus mutans enhance survival in acidic environments. Appl Environ Microbiol 70(2):929-936. https://doi.org/10.1128/ aem.70.2.929-936.2004

Froissard M, D'Andrea S, Boulard C, Chardot T (2009) Heterologous expression of AtClo1, a plant oil body protein, induces lipid accumulation in yeast. FEMS Yeast Res 9:428-438

Fujita Y, Matsuoka H, Hirooka K (2007) Regulation of fatty acid metabolism in bacteria. Mol Microbiol 66(4):829-839. https://doi.org/10.111 1/j.1365-2958.2007.05947.x

Fukui S, Tanaka A (1981) Metabolism of alkanes by yeasts, vol 19. In: Advances in biochemical engineering

Fulco AJ (1970) The biosynthesis of unsaturated fatty acids by bacilli. II. Temperature-dependent biosynthesis of polyunsaturated fatty acids. J Biol Chem 245(11):2985-2990

Fulco AJ (1983) Fatty acid metabolism in bacteria. Prog Lipid Res 22(2):133160. https://doi.org/10.1016/0163-7827(83)90005-x

Fuster G, Schuhmacher M, Domingo JL (2001) Flow analysis of PCDD/Fs for Tarragona Province, Spain. A preliminary inventory. Environ Sci Pollut Res Int 8(2):91-94. https://doi.org/10.1007/BF02987300

Gavrilescu M, Chisti Y (2005) Biotechnology — a sustainable alternative for chemical industry. Biotechnol Adv 23(7-8):471-499. https://doi. org/10.1016/j.biotechadv.2005.03.004

Geyer HJ, Scheunert I, Rapp K, Gebefugi I, Steinberg C, Kettrup A (1993) The relevance of fat content in toxicity of lipophilic chemicals to terrestrial animals with special reference to dieldrin and 2,3,7,8-tetrachlorodibenzo-p-dioxin (TCDD). Ecotoxicol Environ Saf 26(1):45-60. https://doi. org/10.1006/eesa.1993.1040

Guinebretiere MH, Auger S, Galleron N, Contzen M, De Sarrau B, De Buyser ML, Lamberet G, Fagerlund A, Granum PE, Lereclus D, De Vos P, Nguyen-The C, Sorokin A (2013) Bacillus cytotoxicus sp. nov. is a novel thermotolerant species of the Bacillus cereus Group occasionally associated with food poisoning. Int J Syst Evol Microbiol 63(Pt 1):31-40. https://doi. org/10.1099/ijs.0.030627-0

Gurr MI, Harwood JL, Mitchell R, Frayn KN, Murphy DJ (2016) Lipids: biochemistry, biotechnology and health, 6th edn. Wiley/Blackwell, Oxford, p 448

Habe H, Chung JS, Lee JH, Kasuga K, Yoshida T, Nojiri H, Omori T (2001) Degradation of chlorinated dibenzofurans and dibenzo-p-dioxins by two types of bacteria having angular dioxygenases with different features. Appl Environ Microbiol 67(8):3610-3617. https://doi.org/10.1128/ AEM.67.8.3610-3617.2001

Hanano A, Burcklen M, Flenet M, Ivancich A, Louwagie M, Garin J, Blee E (2006) Plant seed peroxygenase is an original heme-oxygenase with an EFhand calcium binding motif. J Biol Chem 281(44):33140-33151. https:// doi.org/10.1074/jbc.M605395200

Hanano A, Al-Arfi M, Shaban M, Daher A, Shamma M (2014a) Removal of petroleum-crude oil from aqueous solution by Saccharomyces cerevisiae SHSY strain necessitates at least an inducible CYP450ALK homolog gene. J Basic Microbiol 54(5):358-368. https://doi.org/10.1002/ jobm.201200525

Hanano A, Almousally I, Shaban M (2014b) Phytotoxicity effects and biological responses of Arabidopsisthaliana to 2,3,7,8-tetrachlorinated dibenzop-dioxin exposure. Chemosphere 104:76-84. https://doi.org/10.1016/j. chemosphere.2013.10.060

Hanano A, Ammouneh H, Almousally I, Alorr A, Shaban M, Alnaser AA, Ghanem I (2014c) Traceability of polychlorinated dibenzo-dioxins/ furans pollutants in soil and their ecotoxicological effects on genetics, functions and composition of bacterial community. Chemosphere 108:326-333. https://doi.org/10.1016/j.chemosphere.2014.01.061

Hanano A, Almousally I, Shaban M, Blee E (2015a) A caleosin-like protein with peroxygenase activity mediates Aspergillus flavus development, aflatoxin accumulation, and seed infection. Appl Environ Microbiol 81(18):6129-6144. https://doi.org/10.1128/AEM.00867-15

Hanano A, Almousally I, Shaban M, Moursel N, Shahadeh A, Alhajji E (2015b) Differential tissue accumulation of 2,3,7,8-tetrachlorinated dibenzo-pdioxin in Arabidopsis thaliana affects plant chronology, lipid metabolism and seed yield. BMC Plant Biol 15:193. https://doi.org/10.1186/ s12870-015-0583-5

Hanano A, Shaban M, Almousally I, Al-Ktaifani M (2015c) Saccharomyces cerevisiae SHSY detoxifies petroleum n-alkanes by an induced CYP52A58 and an enhanced order in cell surface hydrophobicity. Chemosphere 135:418-426. https://doi.org/10.1016/j.chemosphere.2014.11.011

Hanano A, Almousally I, Shaban M, Rahman F, Blee E, Murphy DJ (2016a) Biochemical, transcriptional, and bioinformatic analysis of lipid droplets from seeds of date palm (Phoenix dactylifera L.) and their use as potent sequestration agents against the toxic pollutant, 2,3,7,8-tetrachlorinated dibenzo-p-dioxin. Front Plant Sci 7:836. https://doi.org/10.3389/ fpls.2016.00836

Hanano A, Almousally I, Shaban M, Rahman F, Hassan M, Murphy DJ (2016b) Specific caleosin/peroxygenase and lipoxygenase activities are tissuedifferentially expressed in date palm (Phoenix dactylifera L.) seedlings and are further induced following exposure to the toxin 2,3,7,8-tetrachlorodibenzo-p-dioxin. Front Plant Sci 7:2025. https://doi.org/10.3389/ fpls.2016.02025

Hanano A, Shaban M, Almousally I (2017) Biochemical, molecular, and transcriptional highlights of the biosynthesis of an effective biosurfactant produced by Bacillussafensis $\mathrm{PHA}$, a petroleum-dwelling bacteria. Front Microbiol 8:77. https://doi.org/10.3389/fmicb.2017.00077

Hanano A, Alkara M, Almousally I, Shaban M, Rahman F, Hassan M, Murphy DJ (2018a) The peroxygenase activity of the Aspergillus flavus caleosin, AfPXG, modulates the biosynthesis of aflatoxins and their trafficking and extracellular secretion via lipid droplets. Front Microbiol 9:158. https://doi.org/10.3389/fmicb.2018.00158

Hanano A, Almousally I, Shaban M, Murphy DJ (2018b) Arabidopsis plants exposed to dioxin result in a WRINKLED seed phenotype due to 205 proteasomal degradation of WRI1. J Exp Bot 69(7):1781-1794. https:// doi.org/10.1093/jxb/ery027

Hanano A, Almousally I, Shaban M, Murphy DJ (2018c) Exposure of arabidopsis plants to dioxin results in a wrinkled seed phenotype that is likely due to 205 proteasomal degradation of WRI1. J Exp Bot. https://doi. org/10.1093/jxb/ery027

Hanano A, Shaban M, Almousally I, Murphy DJ (2018d) Identification of a dioxin-responsive oxylipin signature in roots of date palm: involvement of a 9-hydroperoxide fatty acid reductase, caleosin/peroxygenase PdPXG2. Sci Rep 8(1):13181. https://doi.org/10.1038/s41598-018-31342 $-4$

Hanano A, Almousally I, Shaban M (2019a) Exposure of Aspergillus flavus NRRL 3357 to the environmental toxin, 2,3,7,8-tetrachlorinated dibenzo-pdioxin, results in a hyper aflatoxicogenic phenotype: a possible role for caleosin/peroxygenase (AfPXG). Front Microbiol 10:2338. https://doi. org/10.3389/fmicb.2019.02338

Hanano A, Shaban M, Almutlk D, Almousally I (2019b) The cytochrome P450BM-1 of Bacillusmegaterium A14K is induced by 2,3,7,8-tetrachlorinated dibenzo-p-dioxin: biophysical, molecular and biochemical determinants. Chemosphere 216:258-270. https://doi.org/10.1016/j. chemosphere.2018.10.103

Hanson KB, Hoff DJ, Lahren TJ, Mount DR, Squillace AJ, Burkhard LP (2019) Estimating n-octanol-water partition coefficients for neutral highly hydrophobic chemicals using measured n-butanol-water partition coefficients. Chemosphere 218:616-623. https://doi.org/10.1016/j. chemosphere.2018.11.141

Haq I, Raj A (2020) Pulp and paper mill wastewater: ecotoxicological effects and bioremediation approaches for environmental safety. In: Bharagava R, Saxena G (eds) Bioremediation of industrial waste for environmental safety. Springer, Singapore

Harmsen J, Rulkens WH, Eijsackers HJP (2005) Bioavailability: concept for understanding or tool for predicting? Land Contam Reclam 13:161-171 
Hatzinger PB, Alexander M (1995) Effect of aging of chemicals in soil on their biodegradability and extractability. Environ Sci Technol 29:537-545

Hay A (1981) Chlorinated dioxins and the environment. Nature 289(5796):351352. https://doi.org/10.1038/289351a0

Heipieper HJ, Meinhardt F, Segura A (2003) The cis-trans isomerase of unsaturated fatty acids in Pseudomonas and Vibrio: biochemistry, molecular biology and physiological function of a unique stress adaptive mechanism. FEMS Microbiol Lett 229(1):1-7. https://doi.org/10.1016/S0378 -1097(03)00792-4

Hermanson MH, Isaksson E, Divine D, Teixeira C, Muir DCG (2020) Atmospheric deposition of polychlorinated biphenyls to seasonal surface snow at four glacier sites on Svalbard, 2013-2014. Chemosphere 243:125324. https://doi.org/10.1016/j.chemosphere.2019.125324

Hippelein M, Kaupp H, Dörr G, McLachlan M, Hutzinger O (1996) Baseline contamination assessment for a new resource recovery facility in Germany part II: atmospheric concentrations of PCDD/F. Chemosphere 32:1605-1616

Hiraishi A, Miyakoda H, Lim BR, Hu HY, Fujie K, Suzuki J (2001) Toward the bioremediation of dioxin-polluted soil: structural and functional analyses of in situ microbial populations by quinone profiling and culturedependent methods. Appl Microbiol Biotechnol 57(1-2):248-256

Hiraishi A, Iwasaki M, Kawagishi T, Yoshida N, Narihiro T, Kenji Kato K (2003a) Significance of lipoquinones as quantitative biomarkers of bacterial populations in the environment. Microbes Environ 18:89-93

Hiraishi A, Narihiro T, Yamanaka Y (2003b) Microbial community dynamics during start-up operation of flowerpot-using fed-batch reactors for composting of household biowaste. Environ Microbiol 5(9):765-776

Holtwick R, Keweloh H, Meinhardt F (1999) cis/trans isomerase of unsaturated fatty acids of Pseudomonasputida P8: evidence for a heme protein of the cytochrome c type. Appl Environ Microbiol 65(6):2644-2649

Hong C, Chen Y, Li L, Chen S, Wei X (2017) Identification of a key gene involved in branched-chain short fatty acids formation in natto by transcriptional analysis and enzymatic characterization in Bacillus subtilis. J Agric Food Chem 65(8):1592-1597. https://doi.org/10.1021/acs.jafc.6b05518

Hutin D, Tamblyn L, Gomez A, Grimaldi G, Soedling H, Cho T, Ahmed S, Lucas C, Kanduri C, Grant DM, Matthews J (2018) Hepatocyte-specific deletion of TIPARP, a negative regulator of the aryl hydrocarbon receptor, is sufficient to increase sensitivity to dioxin-induced wasting syndrome. Toxicol Sci. https://doi.org/10.1093/toxsci/kfy136

Inouye K, Shinkyo R, Takita T, Ohta M, Sakaki T (2002) Metabolism of polychlorinated dibenzo-p-dioxins (PCDDs) by human cytochrome P450-dependent monooxygenase systems. J Agric Food Chem 50(19):5496-5502

IPCS (2003) Polychlorinated biphenyls: human health aspects. Geneva: World Health Organization, International Programme on Chemical Safety (Concise International Chemical Assessment Document 55. https:// www.inchem.org/documents/cicads/cicads/cicad55.htm)

ISO/FDIS (2008) Soil quality - requirements and guidance for the selection and application of methods for the assessment of bioavailability of contaminants in soil and soil materials. https://www.isoorg/commi ttee/54408.htm

Jacobs MW, Coates JA, Delfino JJ, Bitton G, Davis WM, Garcia KL (1993) Comparison of sediment extract microto ${ }^{\circledR}$ toxicity with semi-volatile organic priority pollutant concentrations. Arch Environ Contam Toxicol 24:461-468

Jamme F, Vindigni JD, Mechin V, Cherifi T, Chardot T, Froissard M (2013) Single cell synchrotron FT-IR microspectroscopy reveals a link between neutral lipid and storage carbohydrate fluxes in S. cerevisiae. PLoS ONE 8:e74421

Jin R, Bu D, Liu G, Zheng M, Lammel G, Fu J, Yang L, Li C, Habib A, Yang Y, Liu $X(2020)$ New classes of organic pollutants in the remote continental environment-chlorinated and brominated polycyclic aromatic hydrocarbons on the Tibetan Plateau. Environ Int 137:105574. https:// doi.org/10.1016/j.envint.2020.105574

Kainou K, Kamisaka Y, Kimura K, Uemura H (2006) Isolation of Delta 12 and omega3-fatty acid desaturase genes from the yeast Kluyveromyces lactis and their heterologous expression to produce linoleic and alphalinolenic acids in Saccharomyces cerevisiae. Yeast 23(8):605-612. https:// doi.org/10.1002/yea.1378

Kakirde KS, Parsley LC, Liles MR (2010) Size does matter: application-driven approaches for soil metagenomics. Soil Biol Biochem 42(11):1911-1923. https://doi.org/10.1016/j.soilbio.2010.07.021
Kalivas A, Ganopoulos I, Psomopoulos F, Grigoriadis I, Xanthopoulou A, Hatzigiannakis E, Osathanunkul M, Tsaftaris A, Madesis P (2017) Comparative metagenomics reveals alterations in the soil bacterial community driven by N-fertilizer and Amino 16(R) application in lettuce. Genomics data 14:14-17. https://doi.org/10.1016/j.gdata.2017.07.013

Kaneda T (1966) Biosynthesis of branched-chain fatty acids. IV. Factors affecting relative abundance of fatty acids produced by Bacillussubtilis. Can J Microbiol 12(3):501-514

Kaneda T (1977) Fatty acids of the genus Bacillus: an example of branchedchain preference. Bacteriol Rev 41(2):391-418

Keweloh H, Heipieper HJ (1996) Trans unsaturated fatty acids in bacteria. Lipids 31(2):129-137. https://doi.org/10.1007/BF02522611

Kiddee P, Naidu R, Wong MH (2013) Electronic waste management approaches: an overview. Waste Manag 33(5):1237-1250. https://doi. org/10.1016/j.wasman.2013.01.006

Kim BH, Fulco AJ (1983) Induction by barbiturates of a cytochrome P-450-dependent fatty acid monooxygenase in Bacillus megaterium: relationship between barbiturate structure and inducer activity. Biochem Biophys Res Commun 116(3):843-850

Kim KS, Hong KH, Ko YH, Yoon KD, Kim MG (2003) Emission characteristics of PCDD/Fs in diesel engine with variable load rate. Chemosphere 53(6):601-607. https://doi.org/10.1016/S0045-6535(03)00540-X

Kim HS, Kim NR, Choi W (2011) Total fatty acid content of the plasma membrane of Saccharomyces cerevisiae is more responsible for ethanol tolerance than the degree of unsaturation. Biotechnol Lett 33(3):509-515. https://doi.org/10.1007/s10529-010-0465-8

Kimura N, Kamagata Y (2009) Impact of dibenzofuran/dibenzo-p-dioxin amendment on bacterial community from forest soil and ring-hydroxylating dioxygenase gene populations. Appl Microbiol Biotechnol 84(2):365-373. https://doi.org/10.1007/s00253-009-2046-0

Kjeller LO, Rappe C (1995) Time trends in levels, patterns, and profiles for polychlorinated dibenzo-p-dioxins, dibenzofurans, and biphenyls in a sediment core from the baltic proper. Environ Sci Technol 29(2):346-355. https://doi.org/10.1021/es00002a010

Koelmel JP, Napolitano MP, UImer CZ, Vasiliou V, Garrett TJ, Yost RA, Prasad MNV, Godri Pollitt KJ, Bowden JA (2020) Environmental lipidomics: understanding the response of organisms and ecosystems to a changing world. Metabolomics 16(5):56. https://doi.org/10.1007/s1130 6-020-01665-3

Konings WN, Albers SV, Koning S, Driessen AJ (2002) The cell membrane plays a crucial role in survival of bacteria and archaea in extreme environments. Antonie Van Leeuwenhoek 81(1-4):61-72. https://doi. org/10.1023/a:1020573408652

Krauss M, Wilcke W (2003) Polychlorinated naphthalenes in urban soils: analysis, concentrations, and relation to other persistent organic pollutants. Environ Pollut 122(1):75-89. https://doi.org/10.1016/s0269 -7491(02)00285-3

Lakshman MR, Campbell BS, Chirtel SJ, Ekarohita N (1988) Effects of 2,3,7,8-tetrachlorodibenzo-p-dioxin (TCDD) on de novo fatty acid and cholesterol synthesis in the rat. Lipids 904-6:904-906

Lakshman MR, Chirtel SJ, Chambers LL, Coutlakis PJ (1989) Effects of 2,3,7,8-tetrachlorodibenzo-p-dioxin on lipid synthesis and lipogenic enzymes in the rat. J Pharmacol Exp Ther 248(1):62-66

Laroo CA, Schenk CR, Sanchez LJ, McDonald J (2011) Emissions of PCDD/Fs, PCBs, and PAHs from a modern diesel engine equipped with catalyzed emission control systems. Environ Sci Technol 45(15):6420-6428. https ://doi.org/10.1021/es104220f

Latchoumycandane C, Chitra KC, Mathur PP (2003) 2,3,7,8-Tetrachlorodibenzop-dioxin (TCDD) induces oxidative stress in the epididymis and epididymal sperm of adult rats. Arch Toxicol 77:280-284

Lawrence BP, Kerkvliet NI (1998) Role of altered arachidonic acid metabolism in 2,3,7, 8-tetrachlorodibenzo-p-dioxin-induced immune suppression in C57BI/6 mice. Toxicol Sci 42(1):13-22. https://doi.org/10.1006/ toxs.1997.2418

Le TT, Son MH, Nam IH, Yoon H, Kang YG, Chang YS (2017) Transformation of hexabromocyclododecane in contaminated soil in association with microbial diversity. J Hazard Mater 325:82-89. https://doi.org/10.1016/j. jhazmat.2016.11.058

Lee HB, Weng LD, Chau AS (1984) Chemical derivatization analysis of pesticide residues. IX. Analysis of phenol and 21 chlorinated phenols in natural 
waters by formation of pentafluorobenzyl ether derivatives. J Assoc Off Anal Chem 67(6):1086-1091

Loffeld B, Keweloh H (1996) cis/trans isomerization of unsaturated fatty acids as possible control mechanism of membrane fluidity in Pseudomonas putida P8. Lipids 31(8):811-815. https://doi.org/10.1007/BF02522976

Ma J, Horii Y, Cheng J, Wang W, Wu Q, Ohura T, Kannan K (2009) Chlorinated and parent polycyclic aromatic hydrocarbons in environmental samples from an electronic waste recycling facility and a chemical industrial complex in China. Environ Sci Technol 43(3):643-649. https:// doi.org/10.1021/es802878w

Mackay D, Bobra A, Chan DW, Shiu WY (1982) Vapor-pressure correlations for low-volatility environmental chemicals. Environ Sci Technol 16:645-649

Magan N, Fragoeiro S, Bastos C (2010) Environmental factors and bioremediation of xenobiotics using white rot fungi. Mycobiology 38(4):238-248. https://doi.org/10.4489/MYCO.2010.38.4.238

Marple L, Berridge B, Throop L (1986) Measurement of the water-octanol partition coefficient of 2,3,7,8-tetrachlorodibenzo-p-dioxin. Environ Sci Technol 20(4):397-399. https://doi.org/10.1021/es00146a013

Matson RS, Hare RS, Fulco AJ (1977) Characteristics of a cytochrome P-450-dependent fatty acid omega-2 hydroxylase from bacillus megaterium. Biochim Biophys Acta 487(3):487-494

Meijer SN, Harner T. Helm PA, Halsall CJ, Johnston AE, Jones KC (2001) Polychlorinated naphthalenes in U.K. soils: time trends, markers of source, and equilibrium status. Environ Sci Technol 35(21):4205-4213. https://doi. org/10.1021/es010071d

Meric D, Alshawabkeh AN, Shine JP, Sheahan TC (2014) Bioavailability of hydrophobic organic compounds in thin-layered capped sediments. Chemosphere 103:281-289. https://doi.org/10.1016/j.chemospher e.2013.12.017

Mertes F, Mumbo J, Pandelova M, Bernhoft S, Corsten C, Henkelmann B, Bussian BM, Schramm KW (2018) Comparative study of dioxin contamination from forest soil samples (BZE II) by mass spectrometry and EROD bioassay. Environ Sci Pollut Res Int 25(5):3977-3984. https://doi. org/10.1007/s11356-016-7558-4

Miao Y, Johnson NW, Phan T, Heck K, Gedalanga PB, Zheng X, Adamson D, Newell C, Wong MS, Mahendra S (2020) Monitoring, assessment, and prediction of microbial shifts in coupled catalysis and biodegradation of 1,4-dioxane and co-contaminants. Water Res 173:115540. https://doi. org/10.1016/j.watres.2020.115540

Mohammadpour H, Murray WJ, Stohs SJ (1988) 2,3,7,8-Tetrachlorodibenzo-pdioxin (TCDD)-induced lipid peroxidation in genetically responsive and non-responsive mice. Arch Environ Contam Toxicol 17(5):645-650

Mrozik A, Piotrowska-Seget Z, Labuzek S (2004) Changes in whole cell-derived fatty acids induced by naphthalene in bacteria from genus Pseudomonas. Microbiol Res 159(1):87-95. https://doi.org/10.1016/j.micre s.2004.02.001

Murphy DJ (2012) The dynamic roles of intracellular lipid droplets: from archaea to mammals. Protoplasma 249:541-585

Narhi LO, Fulco AJ (1987) Identification and characterization of two functional domains in cytochrome P-450BM-3, a catalytically self-sufficient monooxygenase induced by barbiturates in Bacillus megaterium. J Biol Chem 262(14):6683-6690

Narhi LO, Kim BH, Stevenson PM, Fulco AJ (1983) Partial characterization of a barbiturate-induced cytochrome P-450-dependent fatty acid monooxygenase from Bacillusmegaterium. Biochem Biophys Res Commun 116(3):851-858

Nichols DS, Nichols PD, Russell NJ, Davies NW, McMeekin TA (1997) Polyunsaturated fatty acids in the psychrophilic bacterium Shewanella gelidimarina ACAM 456T: molecular species analysis of major phospholipids and biosynthesis of eicosapentaenoic acid. Biochim Biophys Acta 1347(2-3):164-176. https://doi.org/10.1016/s0005-2760(97)00068-4

Nickels JD, Chatterjee S, Mostofian B, Stanley CB, Ohl M, Zolnierczuk P, Schulz R, Myles DAA, Standaert RF, Elkins JG, Cheng X, Katsaras J (2017a) Bacillus subtilis lipid extract, a branched-chain fatty acid model membrane. J Phys Chem Lett 8(17):4214-4217. https://doi.org/10.1021/acs.jpcle tt.7b01877

Nickels JD, Chatterjee S, Stanley CB, Qian S, Cheng X, Myles DAA, Standaert RF, Elkins JG, Katsaras J (2017b) The in vivo structure of biological membranes and evidence for lipid domains. PLoS Biol 15(5):e2002214. https ://doi.org/10.1371/journal.pbio.2002214
NIEHS U (2017) Dioxins. National Institute of Environmental Health Sciences. https://www.niehs.nih.gov/health/topics/agents/dioxins/index.cfm

Nishimura C, Horii Y, Tanaka S, Asante KA, Ballesteros F Jr, Viet PH, Itai T, Takigami H, Tanabe S, Fujimori T (2017) Occurrence, profiles, and toxic equivalents of chlorinated and brominated polycyclic aromatic hydrocarbons in E-waste open burning soils. Environ Pollut 225:252-260. https://doi.org/10.1016/j.envpol.2016.10.088

Nzihou A, Themelis NJ, Kemiha M, Benhamou Y (2012) Dioxin emissions from municipal solid waste incinerators (MSWIs) in France. Waste Manag 32(12):2273-2277. https://doi.org/10.1016/j.wasman.2012.06.016

Oliveira M, Costa S, Vaz J, Fernandes A, Slezakova K, Delerue-Matos C, Teixeira JP, Carmo Pereira M, Morais S (2020) Firefighters exposure to fire emissions: Impact on levels of biomarkers of exposure to polycyclic aromatic hydrocarbons and genotoxic/oxidative-effects. J Hazard Mater 383:121179. https://doi.org/10.1016/j.jhazmat.2019.121179

Ortiz-Urquiza A, Fan Y, Garrett T, Keyhani NO (2016) Growth substrates and caleosin-mediated functions affect conidial virulence in the insect pathogenic fungus Beauveria bassiana. Microbiology 162(11):19131921. https://doi.org/10.1099/mic.0.000375

Pakiet A, Kobiela J, Stepnowski P, Sledzinski T, Mika A (2019) Changes in lipids composition and metabolism in colorectal cancer: a review. Lipids Health Dis 18(1):29. https://doi.org/10.1186/s12944-019-0977-8

Palmer G, McFadzean R, Killham K, Sinclair A, Paton GI (1998) Use of lux-based biosensors for rapid diagnosis of pollutants in arable soils. Chemosphere 36:2683-2697

Paraszkiewicz K, Bernat P, Kusmierska A, Chojniak J, Plaza G (2018) Structural identification of lipopeptide biosurfactants produced by Bacillus subtilis strains grown on the media obtained from renewable natural resources. J Environ Manage 209:65-70. https://doi.org/10.1016/j.jenvm an.2017.12.033

Pedrotta V, Witholt B (1999) Isolation and characterization of the cis-transunsaturated fatty acid isomerase of Pseudomonas oleovorans GPo12. J Bacteriol 181(10):3256-3261

Plaza GA, Chojniak J, Mendrek B, Trzebicka B, Kvitek L, Panacek A, Prucek R, Zboril R, Paraszkiewicz K, Bernat P (2016) Synthesis of silver nanoparticles by Bacillus subtilis T-1 growing on agro-industrial wastes and producing biosurfactant. IET Nanobiotechnol 10(2):62-68. https://doi. org/10.1049/iet-nbt.2015.0016

Pollitt F (1999) Polychlorinated dibenzodioxins and polychlorinated dibenzofurans. Regul Toxicol Pharmacol 30:63-68

Prokopec SD, Viluksela M, Miettinen HM, Boutros PC, Pohjanvirta R (2020) Transgenerational epigenetic and transcriptomic effects of 2,3,7,8-tetrachlorodibenzo-p-dioxin exposure in rat. Arch Toxicol. https://doi. org/10.1007/s00204-020-02730-5

Quaiser A, Ochsenreiter T, Klenk HP, Kletzin A, Treusch AH, Meurer G, Eck J, Sensen CW, Schleper C (2002) First insight into the genome of an uncultivated crenarchaeote from soil. Environ Microbiol 4(10):603-611. https://doi.org/10.1046/j.1462-2920.2002.00345.x

Rahman F, Hassan M, Rosli R, Almousally I, Hanano A, Murphy DJ (2018) Evolutionary and genomic analysis of the caleosin/peroxygenase (CLO/PXG) gene/protein families in the Viridiplantae. PLoS ONE 13(5):e0196669. https://doi.org/10.1371/journal.pone.0196669

Ratledge C, Wynn JP (2002) The biochemistry and molecular biology of lipid accumulation in oleaginous microorganisms. Adv Appl Microbiol $51: 1-51$

Reischl A, Thoma H, Reissinger M, Hutzinger O (1988) Accumulation of organic air constituents by plant surfaces. Spruce needles for monitoring airborne chlorinated hydrocarbons. Biomed Environ Sci 1(3):304-307

Richterich K, Berger H, Steber J (1998) The 'two-phase closed bottle test'-a suitable method for the determination of "ready biodegradability" of poorly soluble compounds. Chemosphere 37(2):319-326. https://doi. org/10.1016/s0045-6535(98)00049-6

Rondon MR, August PR, Bettermann AD, Brady SF, Grossman TH, Liles MR, Loiacono KA, Lynch BA, MacNeil IA, Minor C, Tiong CL, Gilman M, Osburne MS, Clardy J, Handelsman J, Goodman RM (2000) Cloning the soil metagenome: a strategy for accessing the genetic and functional diversity of uncultured microorganisms. Appl Environ Microbiol 66(6):2541-2547. https://doi.org/10.1128/aem.66.6.2541-2547.2000

Rubilar O, Tortella G, Cea M, Acevedo F, Bustamante M, Gianfreda L, Diez MC (2011) Bioremediation of a Chilean Andisol contaminated with pentachlorophenol (PCP) by solid substrate cultures of white-rot 
fungi. Biodegradation 22(1):31-41. https://doi.org/10.1007/s1053 2-010-9373-9

Ruettinger RT, Fulco AJ (1981) Epoxidation of unsaturated fatty acids by a soluble cytochrome P-450-dependent system from Bacillus megaterium. J Biol Chem 256(11):5728-5734

Russell NJ (1984) Mechanism of thermal adaptation in bacteria: blueprints for survival. Trends Biochem Sci 9:108-112

Russell NJ (1997) Psychrophilic bacteria —-molecular adaptations of membrane lipids. Comp Biochem Physiol A Physiol 118(3):489-493. https://doi. org/10.1016/s0300-9629(97)87354-9

Russell NJ, Fukanaga M (1990) A comparison of thermal adaptation of membrane lipids in psychrophilic and thermophilic bacteria. FEMS Microbiol Rev 75:171-182

Russo E, d'Ippolito G, Fontana A, Sarno D, D'Alelio D, Busseni G, lanora A, von Elert E, Carotenuto Y (2020) Density-dependent oxylipin production in natural diatom communities: possible implications for plankton dynamics. ISME J 14(1):164-177. https://doi.org/10.1038/s41396-019-0518-5

Safe S (1990) Polychlorinated biphenyls (PCBs), dibenzo-p-dioxins (PCDDs), dibenzofurans (PCDFs), and related compounds: environmental and mechanistic considerations which support the development of toxic equivalency factors (TEFs). Crit Rev Toxicol 21(1):51-88. https://doi. org/10.3109/10408449009089873

Sakaki T, Munetsuna E (2010) Enzyme systems for biodegradation of polychlorinated dibenzo-p-dioxins. Appl Microbiol Biotechnol 88(1):23-30. https ://doi.org/10.1007/s00253-010-2765-2

Sakaki T, Shinkyo R, Takita T, Ohta M, Inouye K (2002) Biodegradation of polychlorinated dibenzo-p-dioxins by recombinant yeast expressing rat CYP1A subfamily. Arch Biochem Biophys 401(1):91-98. https://doi. org/10.1016/S0003-9861(02)00036-X

Salamanca M, Chandia C, Hernandez A (2016) Impact of forest fires on the concentrations of polychlorinated dibenzo-p-dioxin and dibenzofurans in coastal waters of central Chile. Sci Total Environ 573:1397-1405. https ://doi.org/10.1016/j.scitotenv.2016.07.113

Sarna LP, Hodge PE, Webster GRB (1984) Octanol-water partition coefficients of chlorinated dioxins and dibenzofurans by reversed-phase HPLC using several C18 columns. Chemosphere 13:975-983

Sato SI, Nam JW, Kasuga K, Nojiri H, Yamane H, Omori T (1997) Identification and characterization of genes encoding carbazole 1,9a-dioxygenase in Pseudomonas sp. strain CA10. J Bacteriol 179(15):4850-4858

Schleper C, DeLong EF, Preston CM, Feldman RA, Wu KY, Swanson RV (1998) Genomic analysis reveals chromosomal variation in natural populations of the uncultured psychrophilic archaeon Cenarchaeum symbiosum. J Bacteriol 180(19):5003-5009

Schloss PD, Handelsman J (2003) Biotechnological prospects from metagenomics. Curr Opin Biotechnol 14(3):303-310. https://doi.org/10.1016/ s0958-1669(03)00067-3

Schwalb H, Narhi LO, Fulco AJ (1985) Purification and characterization of pentobarbital-induced cytochrome P-450BM-1 from Bacillus megaterium ATCC 14581. Biochim Biophys Acta 838(3):302-311

Semple KT, Morriss AWJ, Paton GI (2003) Bioavailability of hydrophobic organic contaminants in soils: fundamental concepts and techniques for analysis. Eur J Soil Sci 54:809-818

Shen JP, Zhang LM, Zheng YM, Zhu YG, He JZ (2007) Methodology and application of soil metagenomics. Ying Yong Sheng Tai Xue Bao 18(1):212-218

Shih M, Lee WS, Chang-Chien GP, Wang LC, Hung CY, Lin KC (2006) Dry deposition of polychlorinated dibenzo-p-dioxins and dibenzofurans (PCDD/Fs) in ambient air. Chemosphere 62(3):411-416. https://doi. org/10.1016/j.chemosphere.2005.04.064

Shinkyo R, Sakaki T, Ohta M, Inouye K (2003a) Metabolic pathways of dioxin by CYP1A1: species difference between rat and human CYP1A subfamily in the metabolism of dioxins. Arch Biochem Biophys 409(1):180-187

Shinkyo R, Sakaki T, Takita T, Ohta M, Inouye K (2003b) Generation of 2,3,7,8-TCDD-metabolizing enzyme by modifying rat CYP1A1 through site-directed mutagenesis. Biochem Biophys Res Commun 308(3):511-517

Shlu WY, Doucette W, Gobas FAPC, Andren A, Mackay D (1988) Physical-chemical properties of chlorinated dibenzo-p-dioxins. Environ Sci Technol 22:651-658

Sikkema J, de Bont JA, Poolman B (1995) Mechanisms of membrane toxicity of hydrocarbons. Microbiol Rev 59(2):201-222
Silbert DF, Ladenson RC, Honegger JL (1973) The unsaturated fatty acid requirement in Escherichia coli. Temperature dependence and total replacement by branched-chain fatty acids. Biochim Biophys Acta 311(3):349-361

Smidova K, Kim S, Hofman J (2017) Bioavailability of five hydrophobic organic compounds to earthworms from sterile and non-sterile artificial soils. Chemosphere 179:222-231. https://doi.org/10.1016/j.chemospher e.2017.03.117

Sollai M, Villanueva L, Hopmans EC, Reichart GJ, Sinninghe Damste JS (2019) A combined lipidomic and 16S rRNA gene amplicon sequencing approach reveals archaeal sources of intact polar lipids in the stratified Black Sea water column. Geobiology 17(1):91-109. https://doi. org/10.1111/gbi.12316

Sousa S, Duffy C, Weitz LH, Glover A, Bär E, Henkler R, Killham K (2009) Use of a lux-modified bacterial biosensor to identify constraints to bioremediation of btex-contaminated sites. Environ Toxicol Chem 17:1039-1045

Ssebugere P, Sillanpaa M, Matovu H, Mubiru E (2019) Human and environmental exposure to PCDD/Fs and dioxin-like PCBs in Africa: a review. Chemosphere 223:483-493. https://doi.org/10.1016/j.chemospher e.2019.02.065

Steinberg SM, Poziomek EJ, Engelmann WH, Rogers KR (1995) A review of environmental applications of bioluminescence measurements. Chemosphere 30:2155-2197

Stella T, Covino S, Cvancarova M, Filipova A, Petruccioli M, D'Annibale A, Cajthaml T (2017) Bioremediation of long-term PCB-contaminated soil by white-rot fungi. J Hazard Mater 324(Pt B):701-710. https://doi. org/10.1016/j.jhazmat.2016.11.044

Stockholm C (2001) Stockholm convention on persistent organic pollutants (POPs). Geneva, Secretariat of the Stockholm Convention. https://chm. pops.int

Stukey JE, McDonough VM, Martin CE (1989) Isolation and characterization of OLE1, a gene affecting fatty acid desaturation from Saccharomycescerevisiae. J Biol Chem 264(28):16537-16544

Sulistyaningdyah WT, Ogawa J, Li QS, Shinkyo R, Sakaki T, Inouye K, Schmid RD, Shimizu S (2004) Metabolism of polychlorinated dibenzo-p-dioxins by cytochrome P450 BM-3 and its mutant. Biotechnol Lett 26(24):18571860. https://doi.org/10.1007/s10529-004-5317-y

Suutari M, Laakso S (1994) Microbial fatty acids and thermal adaptation. Crit Rev Microbiol 20(4):285-328. https://doi.org/10.3109/1040841940 9113560

Suutari M, Liukkonen K, Laakso S (1990) Temperature adaptation in yeasts: the role of fatty acids. J Gen Microbiol 136(8):1469-1474. https://doi. org/10.1099/00221287-136-8-1469

Suzuki MT, Beja O, Taylor LT, Delong EF (2001) Phylogenetic analysis of ribosomal RNA operons from uncultivated coastal marine bacterioplankton. Environ Microbiol 3(5):323-331. https://doi.org/10.104 6/j.1462-2920.2001.00198.x

Tang CH, Lin CY, Sun PP, Lee SH, Wang WH (2018) Modeling the effects of Irgarol 1051 on coral using lipidomic methodology for environmental monitoring and assessment. Sci Total Environ 627:571-578. https://doi. org/10.1016/j.scitotenv.2018.01.276

Tartu S, Lille-Langoy R, Storseth TR, Bourgeon S, Brunsvik A, Aars J, Goksoyr A, Jenssen BM, Polder A, Thiemann GW, Torget V, Routti H (2017) Multiplestressor effects in an apex predator: combined influence of pollutants and sea ice decline on lipid metabolism in polar bears. Sci Rep 7(1):16487. https://doi.org/10.1038/s41598-017-16820-5

Thavasi R, Jayalakshmi S, Balasubramanian T, Banat IM (2008) Production and characterization of a glycolipid biosurfactant from Bacillus megaterium. World J Microbiol Biotechnol 24:917-925

Thavasi R, Jayalakshmi S, Banat IM (2011) Effect of biosurfactant and fertilizer on biodegradation of crude oil by marine isolates of Bacillus megaterium, Corynebacteriumkutscheri and Pseudomonas aeruginosa. Bioresour Technol 102(2):772-778. https://doi.org/10.1016/j.biortech.2010.08.099

Torres JP, Leite C, Krauss T, Weber R (2013) Landfill mining from a deposit of the chlorine/organochlorine industry as source of dioxin contamination of animal feed and assessment of the responsible processes. Environ Sci Pollut Res Int 20(4):1958-1965. https://doi.org/10.1007/s1135 6-012-1073-z

Tratnyek PG, Edwards E, Carpenter L, Blossom S (2020) Environmental occurrence, fate, effects, and remediation of halogenated (semi)volatile 
organic compounds. Environ Sci Process Impacts 22(3):465-471. https ://doi.org/10.1039/d0em90008g

Travis CC, Hattemer-Frey HA (1989) A perspective on dioxin emissions from municipal solid waste incinerators. Risk Anal 9(1):91-97. https://doi. org/10.1111/j.1539-6924.1989.tb01223.x

Tsujimoto S, Ishida T, Takeda T, Ishii Y, Onomura Y, Tsukimori K, Takechi S, Yamaguchi T, Uchi H, Suzuki SO, Yamamoto M, Himeno M, Furue M, Yamada H (2013) Selenium-binding protein 1: its physiological function, dependence on aryl hydrocarbon receptors, and role in wasting syndrome by 2,3,7,8-tetrachlorodibenzo-p-dioxin. Biochim Biophys Acta 1830(6):3616-3624. https://doi.org/10.1016/j.bbagen.2013.03.008

Tsydenova O, Bengtsson M (2011) Chemical hazards associated with treatment of waste electrical and electronic equipment. Waste Manag 31(1):4558. https://doi.org/10.1016/j.wasman.2010.08.014

Tue NM, Goto A, Takahashi S, Itai T, Asante KA, Kunisue T, Tanabe S (2016) Release of chlorinated, brominated and mixed halogenated dioxinrelated compounds to soils from open burning of e-waste in Agbogbloshie (Accra, Ghana). J Hazard Mater 302:151-157. https://doi. org/10.1016/j.jhazmat.2015.09.062

Tuomisto JT, Pohjanvirta R, Unkila M, Tuomisto J (1995) 2,3,7,8-Tetrachlorodibenzo-p-dioxin-induced anorexia and wasting syndrome in rats: aggravation after ventromedial hypothalamic lesion. Eur J Pharmacol 293(4):309-317

Tuppurainen K, Asikainen A, Ruokojarvi P, Ruuskanen J (2003) Perspectives on the formation of polychlorinated dibenzo-p-dioxins and dibenzofurans during municipal solid waste (MSW) incineration and other combustion processes. Acc Chem Res 36(9):652-658. https://doi.org/10.1021/ ar020104+

Van den Berg M, Birnbaum LS, Denison M, De Vito M, Farland W, Feeley M, Fiedler H, Hakansson H, Hanberg A, Haws L, Rose M, Safe S, Schrenk D, Tohyama C, Tritscher A, Tuomisto J, Tysklind M, Walker N, Peterson RE (2006) The 2005 World Health Organization reevaluation of human and Mammalian toxic equivalency factors for dioxins and dioxin-like compounds. Toxicol Sci 93(2):223-241. https://doi.org/10.1093/toxsci/kfl055

Wagner M, Loy A, Nogueira R, Purkhold U, Lee N, Daims H (2002) Microbial community composition and function in wastewater treatment plants. Antonie Van Leeuwenhoek 81 (1-4):665-680. https://doi. org/10.1023/a:1020586312170

WHO (2002) Polychlorinated dibenzodioxins, polychlorinated dibenzofurans, and coplanar polychlorinated biphenyls. In: Safety evaluation of certain food additives and contaminants. Geneva, World Health Organization (WHO Food Additives Series, No 48. https://www.inchem.org/docum ents/jecfa/jecmono/v48je20.htm)

WHO (2016) World Health Organization fact sheet No 225, dioxins and their effects on human health, June 1999. https://www.who.int/mediacentr e/factsheets/fs225/en/

Williams PA, Cosme J, Sridhar V, Johnson EF, McRee DE (2000) Mammalian microsomal cytochrome P450 monooxygenase: structural adaptations for membrane binding and functional diversity. Mol Cell 5(1):121-131

Woeller CF, Thatcher TH, Thakar J, Cornwell A, Smith MR, Jones DP, Hopke PK, Sime PJ, Krahl P, Mallon TM, Phipps RP, Utell MJ (2019) Exposure to heptachlorodibenzo-p-dioxin (HpCDD) regulates microRNA expression in human lung fibroblasts. J Occup Environ Med 61 (Suppl 12):S82-S89. https://doi.org/10.1097/JOM.0000000000001691

Wu YL, Lin LF, Hsieh LT, Wang LC, Chang-Chien GP (2009) Atmospheric dry deposition of polychlorinated dibenzo-p-dioxins and dibenzofurans in the vicinity of municipal solid waste incinerators. J Hazard Mater 162(1):521-529. https://doi.org/10.1016/j.jhazmat.2008.05.075

Xiao K, Yue XH, Chen WC, Zhou XR, Wang L, Xu L, Huang FH, Wan X (2018) Metabolic engineering for enhanced medium chain omega hydroxy fatty acid production in Escherichiacoli. Front Microbiol 9:139. https:// doi.org/10.3389/fmicb.2018.00139

Xu C, Hu J, Wu J, Wei B, Zhu Z, Yang L, Zhou T, Jin J (2020) Polychlorinated naphthalenes, polychlorinated dibenzo-p-dioxins and dibenzofurans, and polychlorinated biphenyls in soils in an industrial park in Northwestern China: levels, source apportionment, and potential human health risks. Ecotoxicol Environ Saf 188:109895. https://doi. org/10.1016/j.ecoenv.2019.109895

Yao H, Lu S, Zhang X, Pei J, Lu YT (2018) Pollution status and risks of dioxin-like polychlorinated biphenyls in the soil of the yellow river. Huan jing ke $x u e=$ Huanjing kexue 39(1):123-129. https://doi.org/10.13227 j.j.hkx.201704100

Yuk HG, Marshall DL (2004) Adaptation of Escherichia coli O157:H7 to pH alters membrane lipid composition, verotoxin secretion, and resistance to simulated gastric fluid acid. Appl Environ Microbiol 70(6):3500-3505. https://doi.org/10.1128/AEM.70.6.3500-3505.2004

Zeng FS, Menardo F, Xue MF, Zhang XJ, Gong SJ, Yang LJ, Shi WQ, Yu DZ (2017) Transcriptome analyses shed new insights into primary metabolism and regulation of Blumeria graminis f. sp. tritici during conidiation. Front Plant Sci 8:1146. https://doi.org/10.3389/fpls.2017.01146

Zhang M, Buekens A, Li X (2016) Brominated flame retardants and the formation of dioxins and furans in fires and combustion. J Hazard Mater 304:26-39. https://doi.org/10.1016/j.jhazmat.2015.10.014

Zhao Y, Chen XY, Xu DY, Zhang SY, Chen ZY (2014) Determination of chlorine in gasoline by inductively coupled plasma atomic emission spectrometry. Guang pu xue yu guang pu fen xi = Guang pu 34(12):3406-3410

Zheng GJ, Leung AO, Jiao LP, Wong MH (2008) Polychlorinated dibenzo-pdioxins and dibenzofurans pollution in China: sources, environmental levels and potential human health impacts. Environ Int 34(7):10501061. https://doi.org/10.1016/j.envint.2008.02.011

Zhu Z, Ding Y, Gong Z, Yang L, Zhang S, Zhang C, Lin X, Shen H, Zou H, Xie Z, Yang F, Zhao X, Liu P, Zhao ZK (2015) Dynamics of the lipid droplet proteome of the Oleaginous yeast rhodosporidium toruloides. Eukaryot Cell 14(3):252-264. https://doi.org/10.1128/EC.00141-14

\section{Publisher's Note}

Springer Nature remains neutral with regard to jurisdictional claims in published maps and institutional affiliations.

\section{Submit your manuscript to a SpringerOpen ${ }^{\circ}$ journal and benefit from:}

- Convenient online submission

- Rigorous peer review

- Open access: articles freely available online

- High visibility within the field

- Retaining the copyright to your article

Submit your next manuscript at $\boldsymbol{\nabla}$ springeropen.com 